\title{
Sulfur Protects Pakchoi (Brassica chinensis L.) Seedlings against Cadmium Stress by Regulating Ascorbate-Glutathione Metabolism
}

\author{
Lili Lou ${ }^{1}$, Jingquan Kang ${ }^{1}$, Hongxi Pang ${ }^{2}$, Qiuyu $\mathrm{Li}^{3}{ }^{3}$, Xiaoping Du ${ }^{1}$, Wei Wu ${ }^{1}$, Junxiu Chen ${ }^{1}$ \\ and Jinyin $\mathrm{Lv}^{1, *}$ \\ 1 College of Life Sciences, Northwest A\&F University, Yangling 712100, China; 18829784866@163.com (L.L.); \\ jingquan_kang@163.com (J.K.); duxiaoping@aliyun.com (X.D.); wuwei9585@163.com (W.W.); \\ chenjunxiu1995@gmail.com (J.C.) \\ 2 College of Agronomy, Northwest A\&F University, Yangling 712100, China; hxpang@163.com \\ 3 Innovation Experimental College, Northwest A\&F University, Yangling 712100, China; \\ 18829349240@163.com \\ * Correspondence: jinyinlv@nwsuaf.edu.cn; Tel.: +86-135-7219-6187
}

Received: 15 June 2017; Accepted: 22 July 2017; Published: 26 July 2017

\begin{abstract}
Cadmium (Cd) pollution in food chains pose a potential health risk for humans. Sulfur (S) is a significant macronutrient that plays a significant role in the regulation of plant responses to diverse biotic and abiotic stresses. However, no information is currently available about the impact of S application on ascorbate-glutathione metabolism (ASA-GSH cycle) of Pakchoi plants under Cd stress. The two previously identified genotypes, namely, Aikangqing (a Cd-tolerant cultivar) and Qibaoqing (a Cd-sensitive cultivar), were utilized to investigate the role of $\mathrm{S}$ to mitigate $\mathrm{Cd}$ toxicity in Pakchoi plants under different $\mathrm{Cd}$ regimes. Results showed that $\mathrm{Cd}$ stress inhibited plant growth and induced oxidative stress. Exogenous application of $S$ significantly increased the tolerance of Pakchoi seedlings suffering from $\mathrm{Cd}$ stress. This effect was demonstrated by increased growth parameters; stimulated activities of the antioxidant enzymes and upregulated genes involved in the ASA-GSH cycle and S assimilation; and by the enhanced ASA, GSH, phytochelatins, and nonprotein thiol production. This study shows that applying $\mathrm{S}$ nutrition can mitigate $\mathrm{Cd}$ toxicity in Pakchoi plants which has the potential in assisting the development of breeding strategies aimed at limiting $\mathrm{Cd}$ phytoaccumulation and decreasing $\mathrm{Cd}$ hazards in the food chain.
\end{abstract}

Keywords: cadmium; sulfur metabolism; ascorbate-glutathione cycle; transcriptional regulation; pakchoi

\section{Introduction}

Heavy metal contamination in the soil has become a severe environmental problem worldwide and thus has attracted considerable attention [1-4]. Among the toxic heavy metals, Cadmium $(\mathrm{Cd})$ is recognized as one of the major widespread environmental pollutants and highly toxic to plants and humans, thus affecting their growth and health [5-7]. Cd is released primarily into the environment by anthropogenic activities, such as those involved in industries for electroplating, leather tanning, metal finishing, steel production, pigment manufacturing, and wastewater irrigation $[7,8]$. Previous studies reported that $\mathrm{Cd}$ can inhibit plant growth and cause diseases in plants by altering the several physiological processes [9-11].

Cadmium is a nonredox metal that cannot produce reactive oxygen species (ROS) via Fenton and Haber-Weiss reactions. However, some studies have demonstrated that oxidative stress is a major component of $\mathrm{Cd}$ phytotoxicity $[12,13]$ and thus mediates cellular damage [6]. Under this condition, plants have evolved a list of complex metabolic strategies to counterbalance toxicity 
due to Cd stress [3]. Some of these strategies are cellular wall binding [14,15], plasma membrane pumping, restriction of uptake and transport [16,17], extra- and intracellular chelation, sequestration in vacuoles [18], antioxidant system composed of enzymatic and non-enzymatic components, and signaling mechanisms $[19,20]$.

Ascorbate-glutathione (ASA-GSH) cycle protects the cells against ROS [21,22]. ASA participates in growth processes, electron transport, or ROS scavenging through ascorbate peroxidase (APX). ASA is oxidized to monohydroascorbate (MDHA) by ascorbic acid oxidase (AAO) and APX. MDHA is an unstable radical with a relatively short lifetime and reduced rapidly to ASA and dehydroascorbate (DHA) [23,24]. MDHA is reduced to ASA according to monodehydroascorbate reductase (MDHAR) using nicotinamide adenine dinucleotide phosphate (NADPH) as electron donor. Furthermore, DHA is reduced to ASA by dehydroascorbate reductase (DHAR). GSH is oxidized to oxidized glutathione (GSSG) when DHA is reduced to ASA. GSSG can be reconverted to GSH by receiving electron from NADPH through the activity of glutathione reductase (GR) [25-27]. This finding confirms the fundamental role of GSH in antioxidative defense. This pathway is also complemented by other antioxidant enzymes, such as glutathione peroxidase and glutathione-S-transferases (GST) [28]. Upregulating the genes encoding these enzymes enables the active ASA-GSH pathway to detoxify various ROS.

Studies have shown that appropriate application of plant nutrients may alleviate the stress-induced negative effects [29], decrease Cd concentration, and increase biomass and grain yield [30,31]. Plant nutrients help alleviate physiological stress caused by excessive Cd [32,33]. Among the various mineral nutrients involved in $\mathrm{Cd}$ detoxification, the role of sulfur $(\mathrm{S})$ in $\mathrm{Cd}$ tolerance is the most significant. It plays a vital role in plant defense responses to stress $[23,34,35]$. $\mathrm{S}$ is a structural constituent of amino acids, coenzymes, proteins, and most defense compounds, including phytochelatins (PCs), GSH, glucosinolates, and vitamins, that protect plants from oxidative damage and adverse environmental stresses [36]. Cysteine is produced via a cascade of enzymatic reactions followed by a series of reactions. It is the substrate for glutathione and PC peptides through key enzymes ( $\gamma$-glutamylcysteine synthetase ( $\gamma$-ECS), glutathione synthetase, and PC synthase) in response to oxidative stresses, such as heavy metal exposure [37-39]. Furthermore, the genes of key enzymes (ATP sulfurylase, $\mathrm{O}$-acetylserine(thiol)lyase, and $\gamma$-ECS) engaged in S assimilation in Pakchoi plants are engaged in $\mathrm{Cd}$ tolerance and detoxification $[38,40]$.

Pakchoi (Brassica chinensis L.) plant is one of the most important leafy cruciferous vegetables widely cultivated in southern China [41,42]. Pakchoi plant possesses a high capacity for Cd accumulation in its leaves; this condition can cause serious potential health risks in people eating Pakchoi plant grown in Cd-polluted areas [43-45]. Therefore, reducing Cd accumulation in the edible parts of this vegetable is essential. Manipulating the enzymes involved in S assimilation, ASA-GSH cycle, and PC content may contribute to Cd detoxification. Thus, the present work is designed to provide insights into the role of $\mathrm{S}$ in alleviating Cd stress, and, to elucidate possible mechanisms of $\mathrm{S}$-mediated physiological changes of $\mathrm{Cd}$ toxicity in Pakchoi seedlings. The influence of $\mathrm{S}$ on $\mathrm{Cd}$-induced changes in two different $\mathrm{Cd}$-tolerating Pakchoi seedlings are studied, particularly with respect to the following variables: growth, $\mathrm{Cd}$ uptake and translocation, tissue lipid peroxidation content, nonprotein thiol (NPT), PCs, ROS production, antioxidant defense enzymes, non-enzymatic antioxidants involved in ASA-GSH cycle, gene expression engaged in S metabolism and ASA-GSH cycle.

\section{Results}

\subsection{Plant Growth Parameters}

The effect of $\mathrm{Cd}$ and $\mathrm{S}$ on the shoot and root growth are shown in Table 1. Cd stress decreased the growth parameters of both cultivars compared with the control (Figure 1). Meanwhile, the suppression effects of $\mathrm{Cd}$ stress on growth characters were stronger in Qibaoqing than those in Aikangqing. The application of $10 \mathrm{mg} \cdot \mathrm{kg}^{-1} \mathrm{Cd}$ caused maximum reduction compared with those control. The fresh 
weight of the shoots and roots was reduced by 11.0, 36.8\% in Aikangqing and 24.5, 17.5\% in Qibaoqing due to 1 and $10 \mathrm{mg} \cdot \mathrm{kg}^{-1}$ soil compared with control. S application markedly decreased the inhibitory effect on plant growth, resulting in the increase in plant height, root length, and fresh weight. Exogenously applied $\mathrm{S}$ alone also caused a slight increase in growth compared with control. The growth parameters (except for the length of the roots in Aikangqing) of the two cultivars were higher under $\mathrm{S}$ treatment alone than those under the other treatments. S application $\left(50 \mathrm{mg} \cdot \mathrm{kg}^{-1}\right)$ favored the growth of plants and rid the toxic effects generated by $\mathrm{Cd}$.

Table 1. Effect of exogenous S (50 mg/ kg) application on growth characteristics of Pakchoi seedlings under different concentrations of $\mathrm{Cd}$ stress for 40 days.

\begin{tabular}{|c|c|c|c|c|c|c|}
\hline Growth Parameters & CK & Cd1 & Cd10 & S & $\mathrm{Cd} 1+\mathrm{S}$ & $\mathrm{Cd} 10+\mathrm{S}$ \\
\hline Shoot fresh weight $\left(\mathrm{g} \cdot\right.$ plant $\left.^{-1}\right)$ & $39.59 \pm 4.43^{b}$ & $35.25 \pm 3.61^{b c}$ & $25.66 \pm 2.84^{c}$ & $52.66 \pm 12.21^{\mathrm{a}}$ & $49.91 \pm 7.89^{\mathrm{a}}$ & $38.42 \pm 8.24^{b c}$ \\
\hline Root fresh weight $\left(\mathrm{g} \cdot\right.$ plant $^{-1}$ ) & $3.18 \pm 0.59^{b}$ & $2.01 \pm 0.38^{\mathrm{cd}}$ & $1.52 \pm 0.37^{\mathrm{d}}$ & $4.18 \pm 0.2^{\mathrm{a}}$ & $2.35 \pm 0.29^{c}$ & $1.62 \pm 0.47^{\mathrm{d}}$ \\
\hline Root long $(\mathrm{cm})$ & $33.25 \pm 0.49^{a}$ & $29.68 \pm 3.06^{a b}$ & $24.12 \pm 4.42^{c}$ & $30.94 \pm 4.95^{\mathrm{ab}}$ & $27.43 \pm 2.51^{\mathrm{ab}}$ & $24.62 \pm 4.23 \mathrm{bc}$ \\
\hline \multicolumn{7}{|l|}{ Qibaoqing } \\
\hline Root fresh weight $\left(\mathrm{g} \cdot\right.$ plant $\left.^{-1}\right)$ & $2.40 \pm 0.46^{\mathrm{b}}$ & $1.98 \pm 0.43^{\mathrm{bc}}$ & $1.77 \pm 0.27^{c}$ & $3.00 \pm 0.43^{\mathrm{a}}$ & $2.23 \pm 0.38^{\mathrm{b}}$ & $2.01 \pm 0.31 \mathrm{bc}$ \\
\hline Root long $(\mathrm{cm})$ & $28.58 \pm 3.57^{a b}$ & $22.46 \pm 1.95^{\mathrm{cd}}$ & $21.08 \pm 2.89^{\mathrm{d}}$ & $29.68 \pm 2.66^{\mathrm{a}}$ & $27.46 \pm 1.19^{a b}$ & $25.78 \pm 2.84^{b c}$ \\
\hline
\end{tabular}

Data are mean $\pm \mathrm{SD}(n=5)$. Different letters indicate significant difference at $p<0.05$.
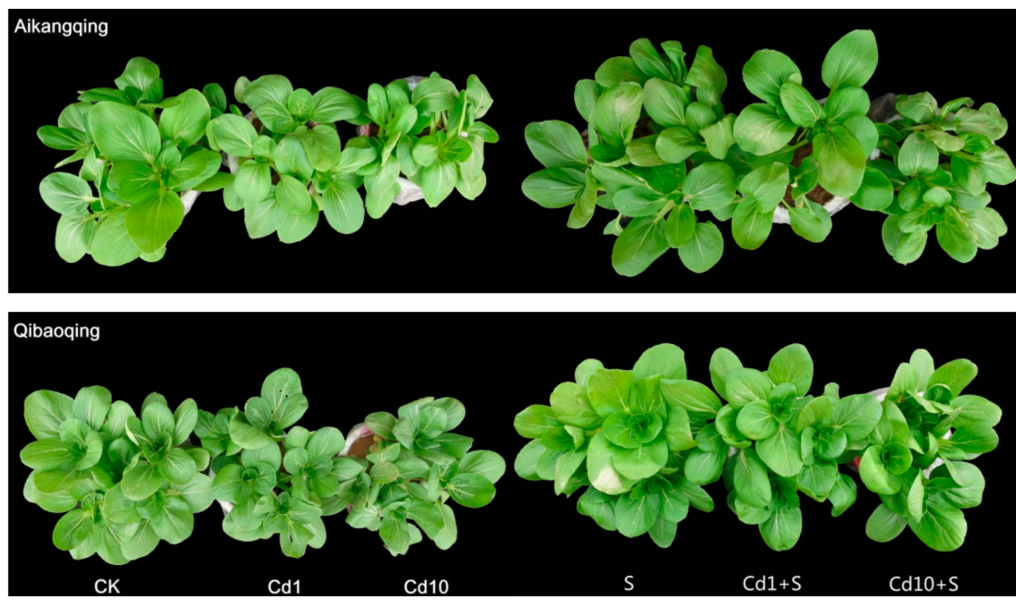

Figure 1. Phenotypes of 40-days-old pakchoi plants grown under different growth conditions of $\mathrm{Cd}$ and S. CK, control; Cd1, $1 \mathrm{mg} \cdot \mathrm{kg}^{-1} \mathrm{Cd} ; \mathrm{Cd} 10,10 \mathrm{mg} \cdot \mathrm{kg}^{-1} \mathrm{Cd} ; \mathrm{S}, 50 \mathrm{mg} \cdot \mathrm{kg}^{-1} \mathrm{~S} ; \mathrm{Cd} 1+\mathrm{S}, 1 \mathrm{mg} \cdot \mathrm{kg}^{-1}$ $\mathrm{Cd}$ and $50 \mathrm{mg} \cdot \mathrm{kg}^{-1} \mathrm{~S} ; \mathrm{Cd} 10+\mathrm{S}, 10 \mathrm{mg} \cdot \mathrm{kg}^{-1} \mathrm{Cd}$ and $50 \mathrm{mg} \cdot \mathrm{kg}^{-1} \mathrm{~S}$. Three independent biological replications were performed with one treatment, and 5 Pakchoi seedlings were planted in a pot.

\subsection{Cadmium Contents, Bioconcentration Factor (BCF) and TF in the Shoots and Roots of Pakchoi Cultivars Subjected to Different Treatments}

Table 2 shows the effect of increasing Cd concentration in the soil. The Cd content in the Pakchoi tissues of Aikangqing and Qibaoqing increased. Exogenous S application significantly caused the reduction of $\mathrm{Cd}$ content in $\mathrm{Cd}$-treated seedlings. $\mathrm{S}$ application caused a decrease of $\mathrm{Cd}$ content by $35.1 \%, 26.8 \%$ in Aikangqing and 34.5\%, 27.9\% in Qibaoqing of the shoots compared with the values recorded in $\mathrm{Cd} 1$ and Cd10-treated seedlings, respectively. In the roots, this decrease was 27.63\%, $27.25 \%$ in Aikangqing and 29.02\%, 20.41\% in Qibaoqing compared with the values recorded in Cd1 and Cd10-treated plants.

The BCF for two cultivars reduced as Cd level increased and S application reduced the value of BCF. In addition, the roots were significantly higher than the shoots in two cultivars and the BCF value in Aikangqing were significantly higher than that in Qibaoqing. A parallel change was also observed 
in TF of Cd. As clearly shown from the data of TF, $\mathrm{S}$ application reduces $\mathrm{Cd}$ translocation from the root to the shoot both in Aikangqing and Qibaoqing.

Table 2. Cadmium contents (mg. $\mathrm{kg}^{-1}$ dry weight), BCF (\%), and TF (\%) in the shoots and roots of Pakchoi cultivars subjected to different treatments.

\begin{tabular}{ccccccc}
\hline \multirow{2}{*}{ Cultivars } & \multirow{2}{*}{ Treatments } & \multicolumn{2}{c}{ Cd Content $\left(\mathbf{m g} \cdot \mathbf{k g}^{\mathbf{- 1}} \mathbf{D W}\right)$} & \multicolumn{2}{c}{ BCF (\%) } & \multirow{2}{*}{ TF (\%) } \\
\cline { 2 - 6 } & & Shoots & Roots & Shoots & Roots & \\
\hline \multirow{3}{*}{ Aikangqing } & $\mathrm{Cd} 1$ & $11.83 \pm 2.09^{\mathrm{b}}$ & $16.14 \pm 2.52^{\mathrm{c}}$ & 1214 & 1656 & 73 \\
& $\mathrm{Cd} 10$ & $45.03 \pm 4.23^{\mathrm{a}}$ & $69.92 \pm 1.67^{\mathrm{a}}$ & 521 & 756 & 69 \\
& $\mathrm{Cd} 1+\mathrm{S}$ & $7.68 \pm 0.39^{\mathrm{b}}$ & $11.68 \pm 0.23^{\mathrm{d}}$ & 772 & 1175 & 66 \\
& $\mathrm{Cd} 10+\mathrm{S}$ & $32.97 \pm 2.71^{\mathrm{a}}$ & $50.86 \pm 3.95^{\mathrm{b}}$ & 352 & 543 & 65 \\
\hline \multirow{3}{*}{ Qibaoqing } & $\mathrm{Cd} 1$ & $9.53 \pm 1.72^{\mathrm{c}}$ & $15.16 \pm 0.22^{\mathrm{c}}$ & 971 & 1544 & 63 \\
& $\mathrm{Cd} 10$ & $34.56 \pm 2.59^{\mathrm{a}}$ & $58.19 \pm 2.65^{\mathrm{a}}$ & 422 & 711 & 59 \\
& $\mathrm{Cd} 1+\mathrm{S}$ & $6.24 \pm 0.84^{\mathrm{c}}$ & $10.76 \pm 0.78^{\mathrm{d}}$ & 647 & 1116 & 58 \\
& $\mathrm{Cd} 10+\mathrm{S}$ & $24.91 \pm 3.28^{\mathrm{b}}$ & $46.31 \pm 1.99^{\mathrm{b}}$ & 268 & 499 & 54 \\
\hline
\end{tabular}

The Cd content of Pakchoi seedlings is uniform, which is zero, because $\mathrm{Cd}$ is not integrated in soil in CK treatment. Different letters in each column indicate significant differences between mean \pm SD of treatments $(n=3)$ at a $p<0.05$ significance level.

\section{3. $\mathrm{H}_{2} \mathrm{O}_{2}$ and $\mathrm{MDA}$ Contents}

MDA and $\mathrm{H}_{2} \mathrm{O}_{2}$ contents in $\mathrm{Cd}$ treatments were also increased with the change of Cd-treated concentration (Figure 2). However, the MDA and $\mathrm{H}_{2} \mathrm{O}_{2}$ contents in $\mathrm{S}$ application plants were considerably lower than those of $\mathrm{Cd}$ treatment alone. These results indicated that exogenous $\mathrm{S}$ application alleviated the accumulation of MDA and $\mathrm{H}_{2} \mathrm{O}_{2}$ induced by Cd. Additionally, the $\mathrm{H}_{2} \mathrm{O}_{2}$ contents of Qibaoqing were significantly higher than that in Aikangqing. Similar trends were also found in the MDA contents.
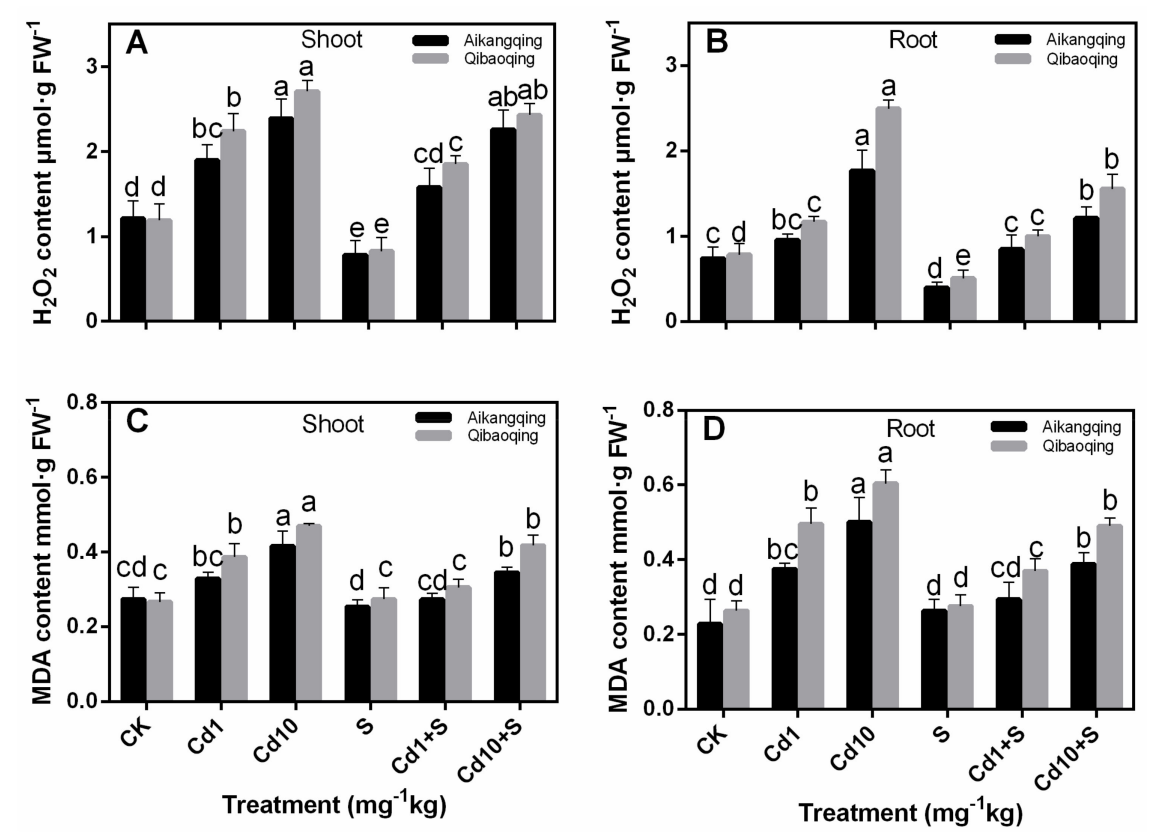

Figure 2. (A,B) Hydrogen peroxide $\left(\mathrm{H}_{2} \mathrm{O}_{2}\right)$ and $(\mathbf{C}, \mathbf{D})$ malondialdehyde (MDA) contents in leaves and roots of Aikangqing and Qibaoqing. The leaves and roots of three seedlings were separately collected in one replication and three independent biological replications were performed. Different letters indicate significant differences at a $p<0.05$ significance level. 


\subsection{Enzymes of S Assimilation Pathway}

ATP sulfurylase (ATPS), O-acetylserine(thiol)lyase (OASTAL), and $\gamma$-glutamylcysteine synthetase $(\gamma$-ECS) are all key enzymes in $S$ assimilation pathway. They showed similar trends in the shoots and roots under $\mathrm{S}$ and $\mathrm{Cd}$ treatments. All the three enzymes improved with increasing $\mathrm{Cd}$ treatments. $\mathrm{S}$ application enhanced their activities. A considerable increase in Aikangqing was observed (Figure 3A-F).

GST activity showed an increasing trend as Cd concentration increased in the soil of both cultivars. $\mathrm{Cd} 10$ and S treatments increased the shoot and root GST activity. The increase was 1.97- and 2.26-fold in Aikangqing $(p<0.05)$ compared with their respective controls (Figure 3G,H). GST activity was also significantly higher in Aikangqing than that in Qibaoqing under the same $\mathrm{Cd}$ and $\mathrm{S}$ exposure, respectively (except for the root at $\mathrm{Cd} 1, \mathrm{~S}$, and $\mathrm{Cd} 1+\mathrm{S}$ treatments).
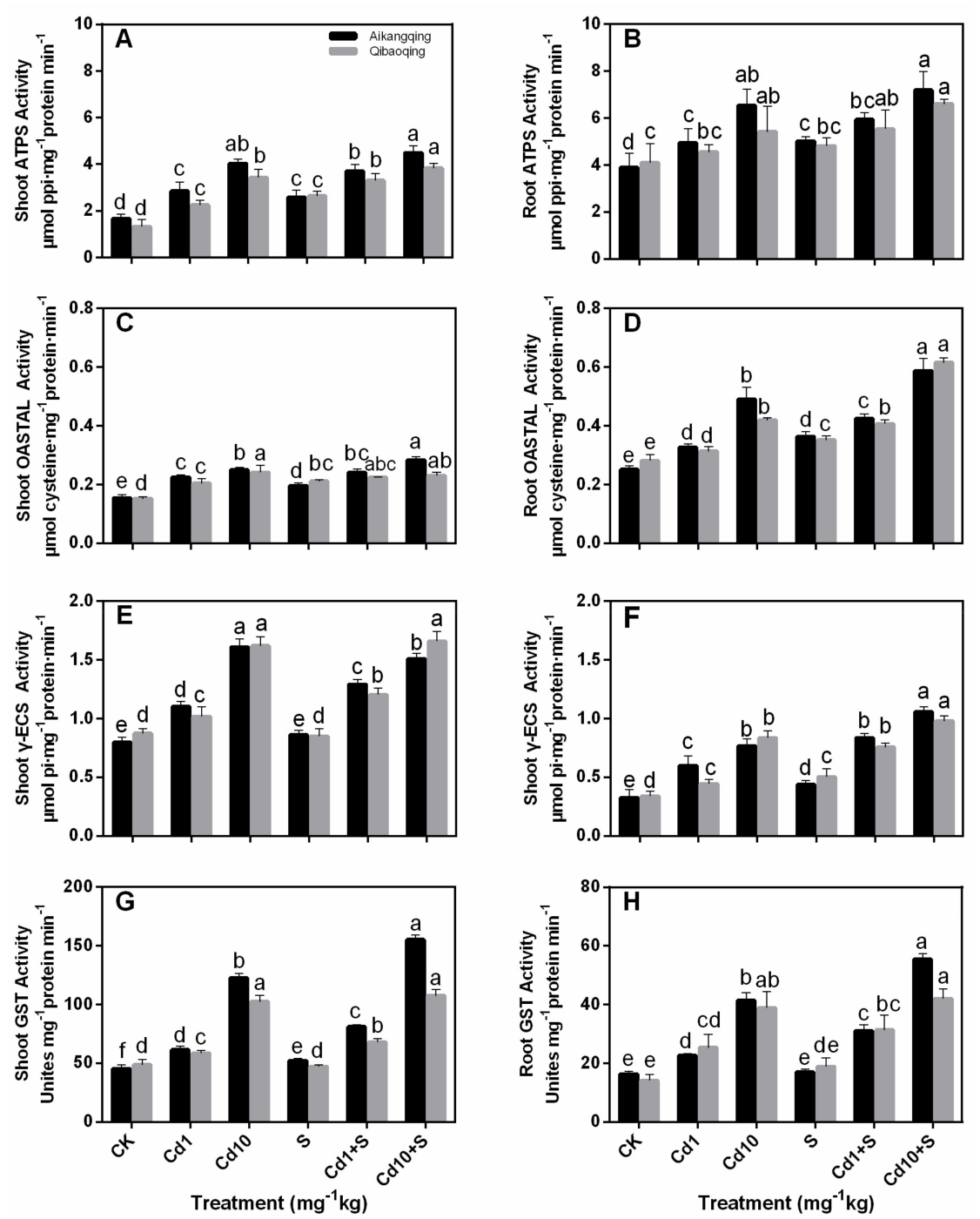

Figure 3. Key enzymes activities of $S$ assimilation pathway and glutathione (GSH) metabolism. (A,B) ATP sulfurylase (ATPS); (C,D) O-acetylserine(thiol)lyase (OASTAL); (E,F) $\gamma$-glutamylcysteine synthetase $(\gamma$-ECS) and $(\mathbf{G}, \mathbf{H})$ GST activity in leaves and roots of Aikangqing and Qibaoqing. The leaves and roots of three seedlings were separately collected in one replication and three independent biological replications were performed. Different letters indicate significant differences at a $p<0.05$ significance level. 


\subsection{Determination of the Activity of Antioxidant Enzymes in the ASA-GSH Cycle}

The four key enzymes that clean ROS via maintaining a highly reduced contents of GSH and ASA, namely, APX, GR, DHAR, and MDHAR, showed similar responses to different treatments in both tissues of the Aikangqing and Qibaoqing cultivars (except DHAR activity) (Figure 4).

The activities of APX, GR, MDHAR, and DHAR were significantly enhanced by Cd1 and Cd10 treatments. Meanwhile, the APX, GR, MDHAR increased with $S$ application. DHAR showed differential response to $S$ under Cd exposure in contrast to APX, GR, and MDHAR, DHAR activity was reduced compared with control.
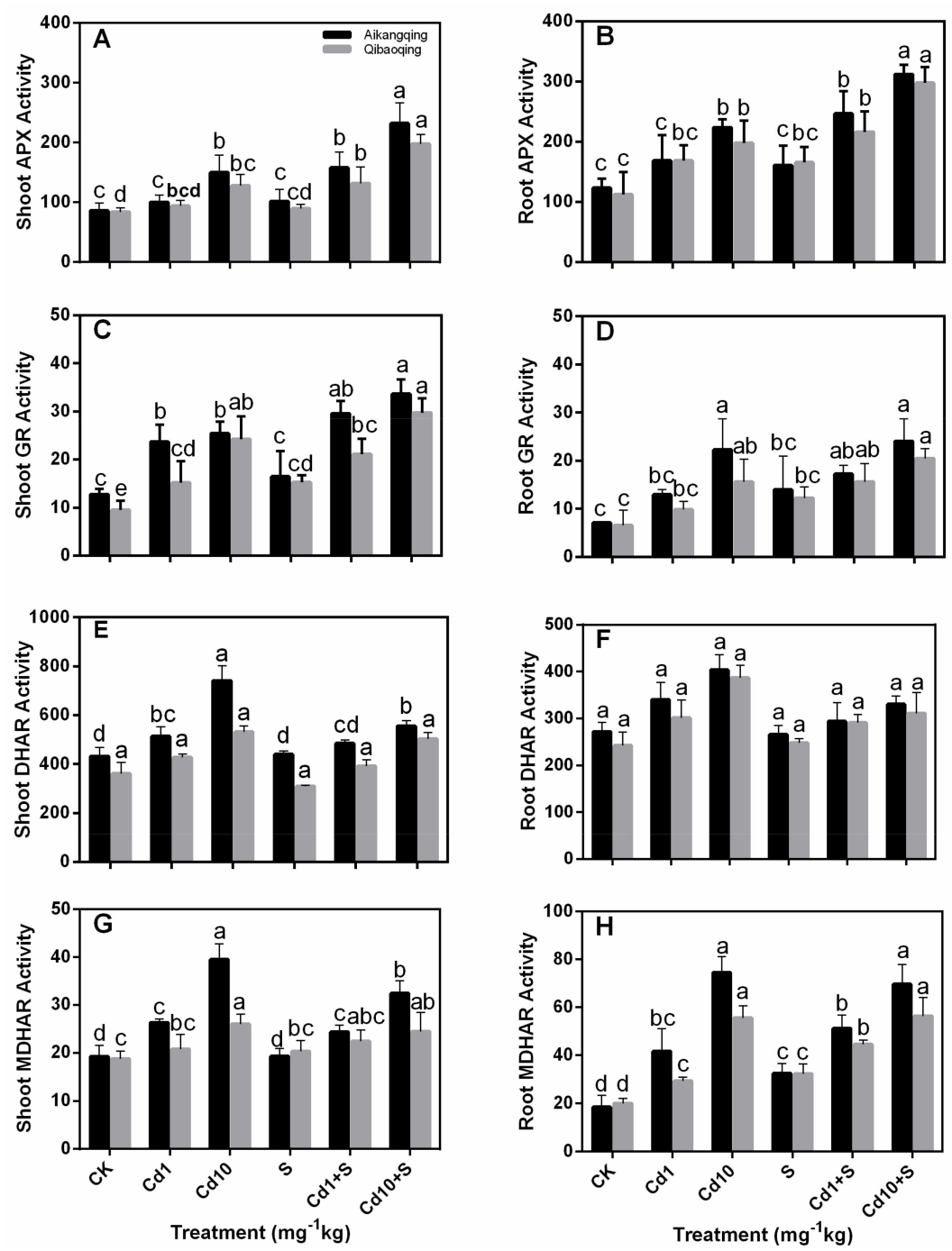

Figure 4. Determination of antioxidant enzymes in the Ascorbate-glutathione (AsA-GSH cycle). $(\mathbf{A}, \mathbf{B})$ ascorbate peroxidase (APX); (C,D) glutathione reductase (GR); (E,F) dehydroascorbate reductase (DHAR) and (G,H) monodehydroascorbate reductase (MDHAR) activity in leaves and roots of Aikangqing and Qibaoqing. The leaves and roots of three seedlings were separately collected in one replication and three independent biological replications were performed. Different letters indicates significant differences $(p<0.05)$. Units of these enzyme activity, $\mathrm{U} \cdot \mathrm{mg}^{-1}$ protein $\cdot \mathrm{min}^{-1}$.

\subsection{Determination of Glutathione, Ascorbate, PCs, and NPT}

Different cadmium concentrations triggered a significant decrease in GSH and ASA content in the shoots and roots of both cultivars compared with control seedlings (Figure 5A,B,G,H). Exogenous $\mathrm{S}$ improved ASA and GSH contents, and declined GSSG and DHA contents in Cd1, as well as in 
Cd10-treated seedlings (Figure 5D,E,J,K). The ratio of GSH relative to GSSG was higher in Aikangqing than that of Qibaoqing. Cd exposure resulted in a lower ratio of GSH relative to GSSG in both cultivars, but the GSH to GSSG ratio was higherer in the S application plants. Similar tendencies were also found in the ratio of ASA relative to DHA.
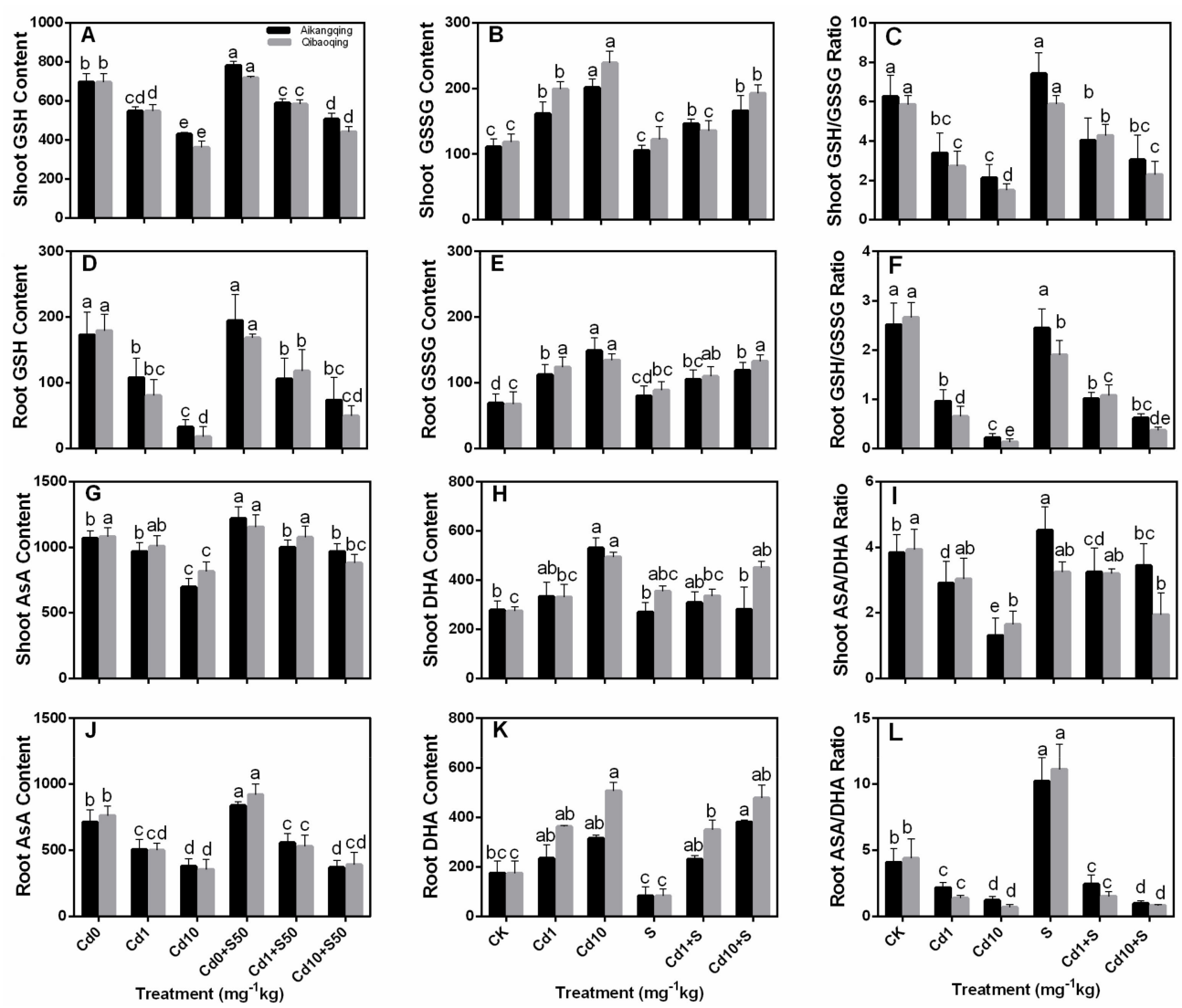

Figure 5. Effects of exogenous $\mathrm{S}$ on content of (A,D) glutathione (GSH); (B,E) oxidized glutathione (GSSG); (G,J) ascorbate (ASA); (H,K) dehydroascorbate (DHA); (C,F) GSH/GSSG ratio, and $(\mathrm{I}, \mathrm{L})$ ASA/DHA ratio in roots and leaves of Pakchoi seedlings suffered from Cd stress. The leaves and roots of three seedlings were separately collected in one replication and three independent biological replications were performed. Different letters indicates significant differences $(p<0.05)$. Units of GSH, GSSG, ASA and DHA content, nmol.g. $\mathrm{FW}^{-1}$.

The NPT content in the roots significantly improved in both cultivars under different $\mathrm{Cd}$ concentration stresses compared with control plants (Figure 6A,B). No significant differences were observed in the shoots. However, the NPT content decreased in the shoots and roots of two cultivars because of interactive $\mathrm{S}$ and $\mathrm{Cd}$ treatments compared with solely $\mathrm{Cd}$-stressed plants.

PCs content drastically increased in both tissues and cultivars treated with Cd1 and Cd10 (Figure 6C,D). S application resulted in reduction of PCs content in both the cultivars compared with Cd-stressed seedlings. S application increased PCs content by $55.8 \%$ and $128 \%$ of the shoots in Aikangqing and Qibaoqing respectively compared with the control plants in the absence of $\mathrm{Cd}$ treatment. However, PCs content reduced by $23.1 \%$ and increased by $20.8 \%$ in the roots of Aikangqing and Qibaoqing respectively compared with control (CK). 

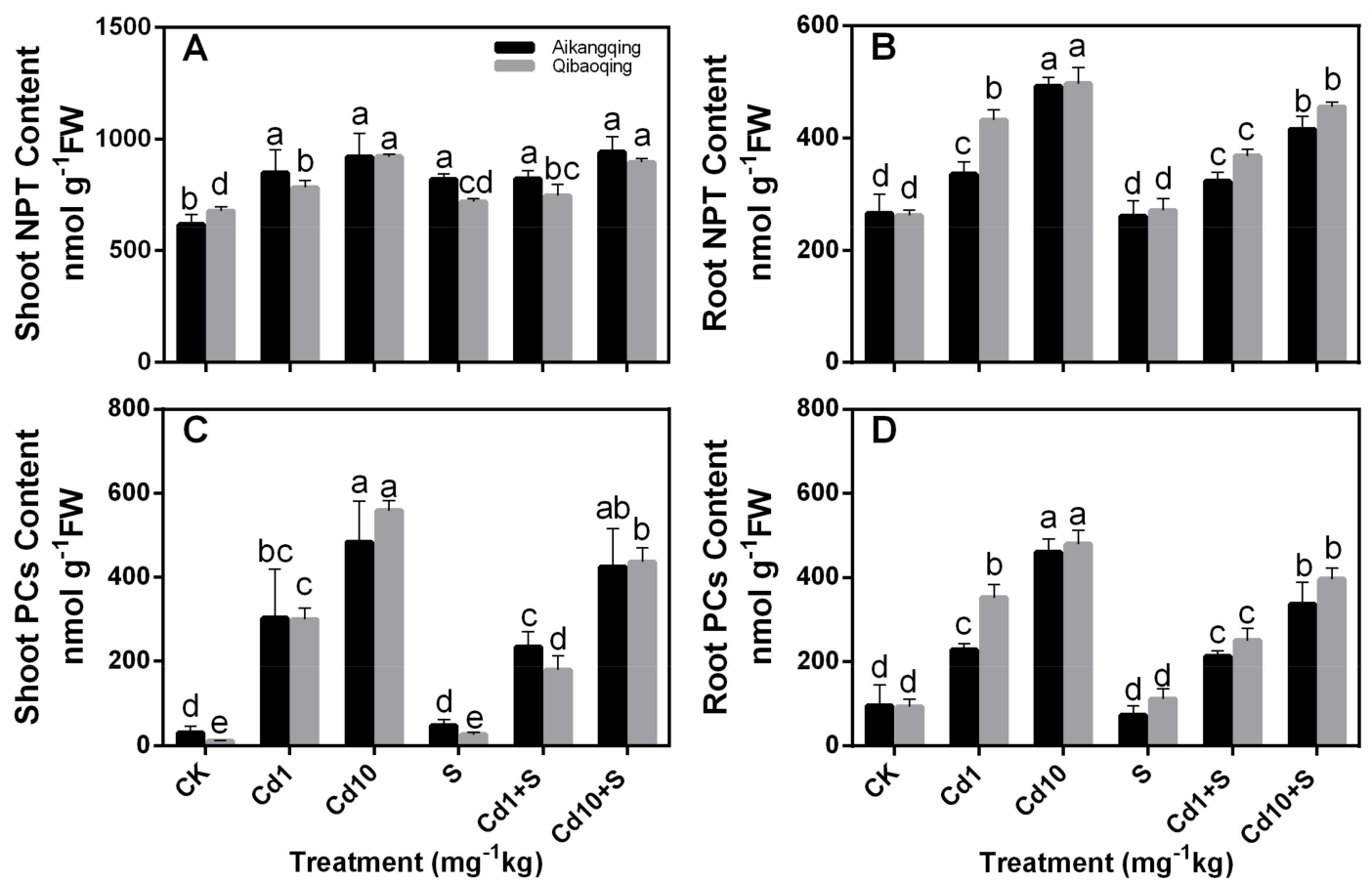

Figure 6. Effects of $S$ addition on (A,B), nonprotein thiol (NPT) and (C,D), phytochelatins (PCs) contents in both tissues of the Pakchoi cultivars Aikangqing and Qibaoqing under Cd stress. Data show the mean \pm SD of three replicates. Different letters indicate significant differences at a $p<0.05$ significance level.

2.7. Transcript Levels of Gene-Encoding Enzymes Involved in S Assimilation Pathway in the Shoots and Roots of Pakchoi Seedlings

GST expression in the Aikangqing shoots and roots was upregulated by Cd treatment. S treatment enhanced expression of GST in the shoots. In the roots, GST expression was downregulated compared with Cd treatment (Figure 7A). Furthermore, the transcription of the GST gene increased sharply at Cd stress in the shoots in Qibaoqing, whereas it increased gradually in the roots. Exogenous $\mathrm{S}$ decreased the transcript levels of the GST gene in the shoots, whereas it was enhanced in the roots (Figure 7B).

ATPS expression in the shoots and roots of both cultivars quickly increased at different levels of $\mathrm{Cd}$ treatment (Figure 7C,D). S and Cd treatment enhanced ATPS expression level, especially in the roots of Aikangqing (2.79-fold) and shoots of Qibaoqing (3.52-fold) compared with the Cd1 treatment. A similar pattern was noted with $\gamma$-ECS gene (Figure 7E,F). However, $\gamma$-ECS expression was much stable than ATPS. The expression levels of $\gamma$-ECS slowly increased in both tissues and cultivars of plants exposed to $\mathrm{Cd}$ and $\mathrm{Cd}+\mathrm{S}$ stress (except in the shoots of Qibaoqing at $\mathrm{Cd} 10$ treatment). 

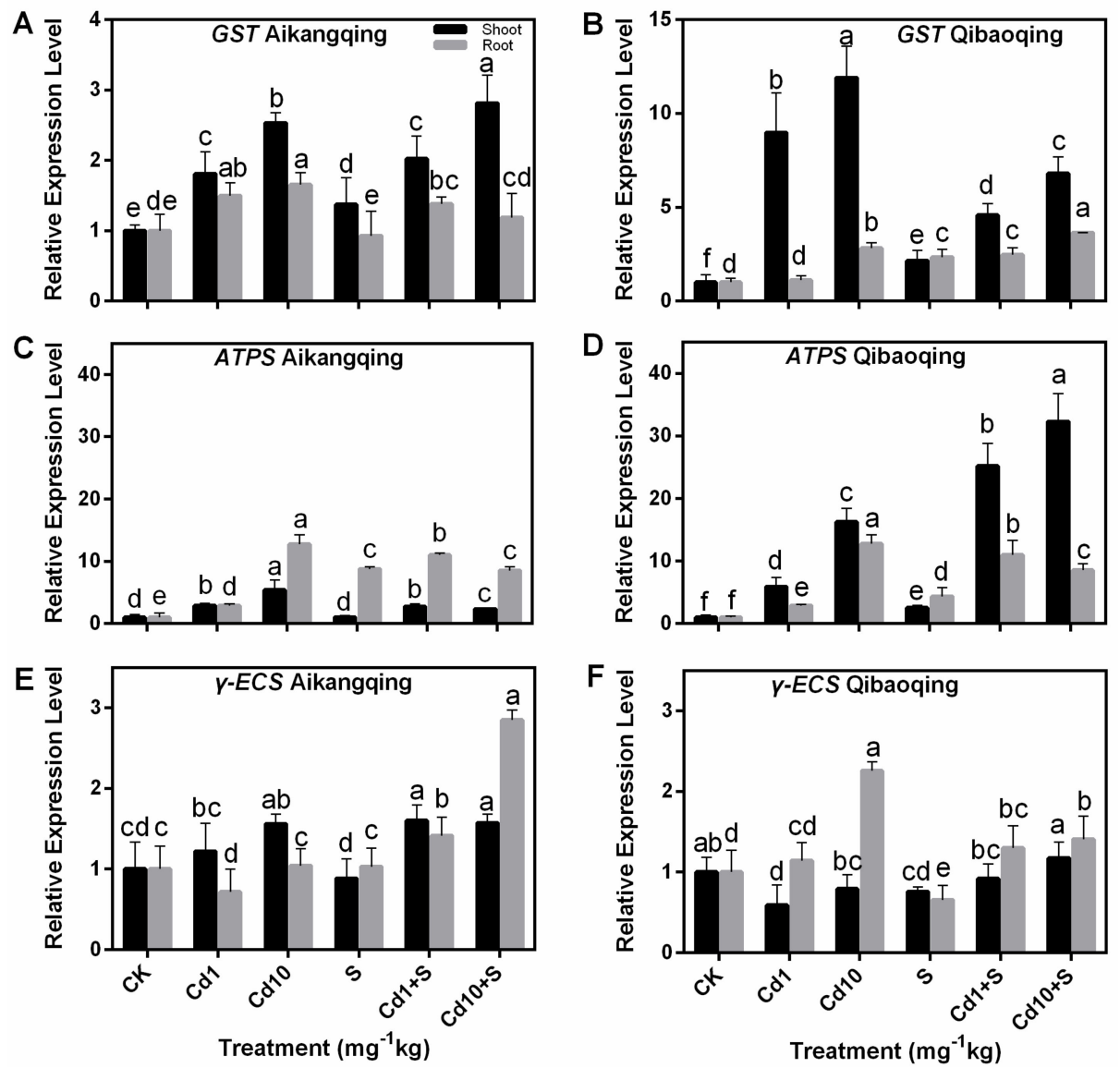

Figure 7. Expression of key enzymes activities of S assimilation pathway and GSH metabolism. Transcripts were analyzed by qPCR using Actin gene as internal control. (A,C,E) transcript levels of GST, ATPS and $\gamma$-ECS genes in Aikangqing; (B,D,F) transcript levels of the three genes in Qibaoqing, respectively. The leaves and roots of three seedlings were collected in one replication and three independent biological replications were performed. Each value is the mean \pm standard deviation of three independent measurements. Different letters indicate significant differences $(p<0.05)$.

\subsection{Transcript Levels of Gene-Encoding Enzymes Involved in ASA-GSH Cycle}

Figure 8 shows that the transcription level of enzymes in ASA-GSH pathway including APX, GR, $D H A R$, and MDHAR increased under Cd stress. The results showed that $\mathrm{S}$ application increased the transcript levels of the four genes in stressed plants. However, their expression patterns were different to some extent (Figure 8). APX expression was markedly induced at $\mathrm{Cd} 1$ treatment, and then decreased at $\mathrm{Cd} 10$ treatment in both tissues and cultivars. Meanwhile, $A P X$ expression in $\mathrm{Cd}+\mathrm{S}$-treated plants was higher than those only exposed to $\mathrm{Cd}$ (Figure 8A,B). GR expression in the roots of Aikangqing remained almost constant but was significantly enhanced in a dose-dependent manner in the shoots. The transcript levels of GR in both tissues of Qibaoqing gradually increased with the increased dose of Cd (Figure 8C,D). Different to the APX expression, DHAR expression was significantly induced at $\mathrm{Cd} 10$ treatment in both tissues and cultivars, and it was enhanced in $\mathrm{Cd}+\mathrm{S}$ treatment (Figure 8E,F). A parallel change was also observed in MDHAR gene (Figure 8G,H). 

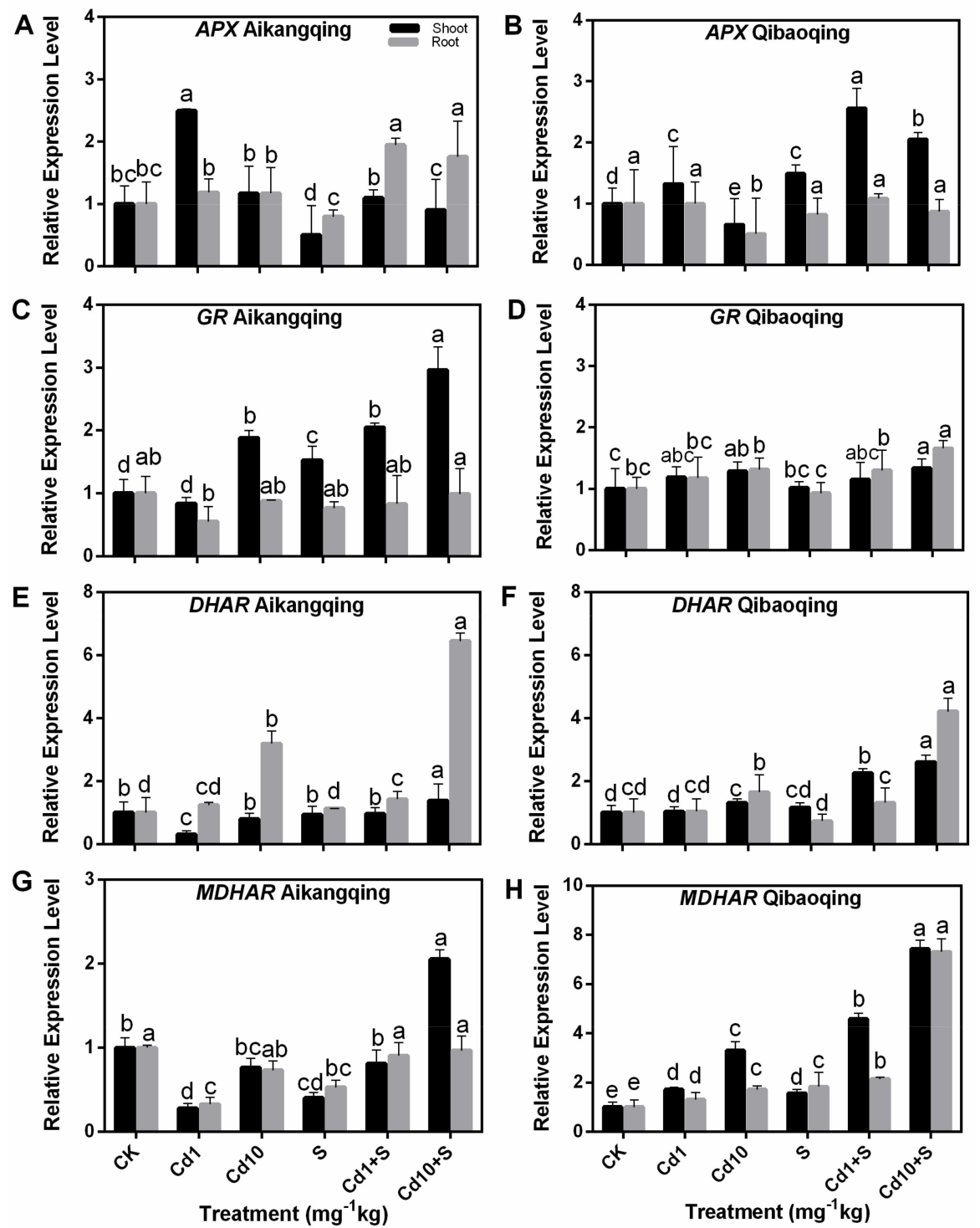

Figure 8. Effects of exogenous $\mathrm{S}$ on transcript levels of the four genes encoding ASA-GSH cycle enzymes in Pakchoi seedlings suffering from Cd stress. Transcripts were analyzed by qPCR using Actin gene as internal control. (A,C,E,G) transcript levels of APX, GR, DHAR and MDHAR genes in Aikangqing; (B,D,F,H) transcript levels of the four genes in Qibaoqing, respectively. The leaves and roots of three seedlings were collected in one replication and three independent biological replications were performed. Each value is the mean \pm standard deviation of three independent measurements. Different letters indicate significant differences $(p<0.05)$.

\section{Discussion}

Cadmium (Cd) has been known as a highly ecotoxic heavy metal and environmental hazard that causes detrimental effects in plant growth and human health [7,46-49]. Alleviation of metal toxicity by sulfur (S) application has been observed in many plant species in previous studies $[34,50,51]$. Moreover, all the results in these studies demonstrated that $S$ addition can enhance plant growth under metal toxicity. The results of the current study supported these findings. Our results showed that exposing two cultivar Pakchoi seedlings to $\mathrm{Cd}$ stress can considerably hamper plant growth in dose dependent manner and sulfur restored the growth (Figure 1, Table 1). The growth inhibition caused by $\mathrm{Cd}$ stress might be due to $\mathrm{Cd}$-induced generation of ROS that involved various factors, such as $\mathrm{H}_{2} \mathrm{O}_{2}$, superoxide radical, and hydroxyl radical promoting the MDA contents through lipid 
peroxidation $[11,52,53]$. The alleviative effects may result from $\mathrm{S}$ involving multiple detoxification mechanisms [54]. The current work supports the hypothesis that sufficient $S$ may enable the chelation of more $\mathrm{Cd}$ in plant roots, subsequently limiting its translocation from root to shoot [55]. We found that $\mathrm{Cd}$ accumulation was greater in the roots, and less was observed in the shoots (Table 2). BCF is a reliable indicator of metal accumulation capacity of plants [56,57]. According to Odjegba and Fasidi [58] and Zayed et al. [59], "a good metal accumulating plant should have a $>1000$ BCF value." The current study shows that BCF value of both the shoots and roots in Aikangqing was higher than 1000, and therefore can be considered to be metal accumulators. $\mathrm{S}$ application reduces $\mathrm{Cd}$ translocation to the shoot in both Aikangqing and Qibaoqing as evident from Cd concentration, TF, and BCF. Thus, improving $\mathrm{S}$ supply might enhance the plant tolerance against $\mathrm{Cd}$ by reducing the translocation from the root to the shoot.

Oxidative stress induced by over production of ROS is a common toxic effect shared by diverse biotic and abiotic stresses [60-63]. The ROS increase may lead to lipid peroxidation indicated by MDA level. This process was also associated to the formation of $\mathrm{H}_{2} \mathrm{O}_{2}$ [64,65]. Therefore, $\mathrm{H}_{2} \mathrm{O}_{2}$ and MDA contents can suggest the level of oxidative stress in plants [66]. Cd stress induced a significant damage effect on Pakchoi plant suggested by the enhanced $\mathrm{H}_{2} \mathrm{O}_{2}$ and lipid peroxidation in both tissues of Aikangqing and Qibaoqing in the current work. However, $\mathrm{S}$ application to $\mathrm{Cd}$-stressed seedlings significantly alleviated Cd-generated oxidative damage (Figure 2). ROS level in plant cells is strictly regulated by an antioxidant system, which comprises enzymatic and non-enzymatic antioxidants [3,65]. ASA and GSH are molecules of major non-enzymatic antioxidants. In addition, the enzymes and antioxidants in "the ASA-GSH pathway play a vital role in preserving the balance between ROS production and scavenging in plants challenged to various abiotic stress conditions" according to $[27,60,67]$. Previous studies demonstrated that stressful conditions can stimulate the antioxidant defense system in different plant species $[27,68,69]$. Most of the antioxidant enzymes in the ASA-GSH pathway (APX, GR, DHAR, and MDHAR) showed significant increases in both tissues of plants under $\mathrm{Cd}$ stress in our study. This result indicates that Pakchoi plant has activated antioxidant defense-system response to $\mathrm{Cd}$ stress. Moreover, the antioxidant enzyme activities in Aikangqing were higher than those in Qibaoqing, which suggested that the role of $S$ application in alleviating abiotic stresses is closely related to the efficiently regulated antioxidant defense system [23,34,70]. Application of exogenous $S$ increased the activities of antioxidant enzymes in the ASA-GSH cycle (APX, GR, DHAR, and MDHAR) and key enzymes of $S$ assimilation pathway (ATPS, $\gamma$-ECS, OASTAL, and GST) caused by $\mathrm{Cd}$ stress as revealed by increased growth parameters (plant height, root length, and fresh weights), and diminished $\mathrm{H}_{2} \mathrm{O}_{2}$ and MDA content in this study (Table 1, Figure 2). These findings suggest that $\mathrm{S}$ application enhances the tolerance of Pakchoi plant to $\mathrm{Cd}$ stress similar to the previous studies in maize [71], rice (Oryza sativa L.) [72], garden cress (Lepidium sativum L.) [47], and yellow mustard (Sinapis alba L.) [73]. This phenomenon may be linked with S application inducing Cd decrease in plant responsible for ROS production.

A negative correlation existed between the $\mathrm{Cd}$ stress and major non-enzymatic antioxidants (ASA and GSH) in Cd-stressed plants, and applying $S$ increased the ASA and GSH contents slightly (Figure 5) similar to the previous studies in mung bean and maize [74,75]. GSH is a precursor of PCs, which plays an important role in controlling cellular heavy metal concentration [76-78]. The depletion of GSH pools can be attributed to the demand in PCs synthesis, one of the most vital components of NPT. However, the thiol pool responses can be partially reversed by supplying S. S application probably regulates GSH content by increasing its biosynthesis. This effect can be seen from the upregulation of $\gamma$-ECS and ATPS activity and transcript levels (Figures 3 and 7). NPT primarily constitute GSH and PCs. NPT content was enhanced under Cd stress and S supply suggesting its importance in Cd detoxification. $\mathrm{S}$ assimilation regulates NPT biosynthesis. The results from our studies indicated that $\mathrm{S}$ application can markedly increase the capabilities of counteracting the impact of oxidative damage triggered by $\mathrm{Cd}$ toxicity in Pakchoi plants. 
In response to $\mathrm{Cd}$ stress, the plant may regulate the expression levels of genes engaged in $\mathrm{S}$ assimilation and ASA-GSH cycle providing an increased flux through the complete pathway when $\mathrm{S}$ is not limiting [79]. Overexpression of S-assimilating enzymes enhances tolerance to heavy metals [38,40]. The expression levels of seven genes encoding key enzymes involved in $S$ assimilation (ATPS, $\gamma$-ECS, and GST) and ASA-GSH pathway enzymes (GR, APX, DHAR, and MDHAR) were determined in $\mathrm{Cd}$-stressed Pakchoi seedlings to identify their associations with the $\mathrm{Cd}$ stress and $\mathrm{S}$ application in our work. The contemporary work showed that plants activate the S-assimilation pathway by increasing the transcription of related genes. This increase can provide a great supply of Cys or GSH for PC biosynthesis under cadmium stress. The transcript profiles of these genes varied in a dose-dependent manner. Most of the transcript levels of the genes were markedly enhanced by $S$ application at different levels of cadmium treatment (Figures 7 and 8). These results are also supported by several previous studies on Indian mustard [80], tobacco [81,82], Brassica rapa [83], Arabidopsis [40,84], and poplar [38].

$S$ uptake results in the initial formation of the first steady product cysteine via a set of enzymatic reactionsare summarized in Figure 9. Cysteine formation results in GSH synthesis, a non-enzymatic antioxidant acknowledged engaged in ASA-GSH cycle to regulate $\mathrm{Cd}$ detoxification either via quenching ROS or biosynthesizing PCs and NPT that combines $\mathrm{Cd}$ and separates it into vacuole. Regulation of key enzymes in S assimilation, ASA-GSH cycle or PCs content might result in Cd detoxification. However, more studies are needed to obtain more insights into the mechanisms of regulation of S assimilation involved in Cd toxicity in Pakchoi plants at molecular level. Evidence on signaling molecules and mechanisms still remains to be clarified.

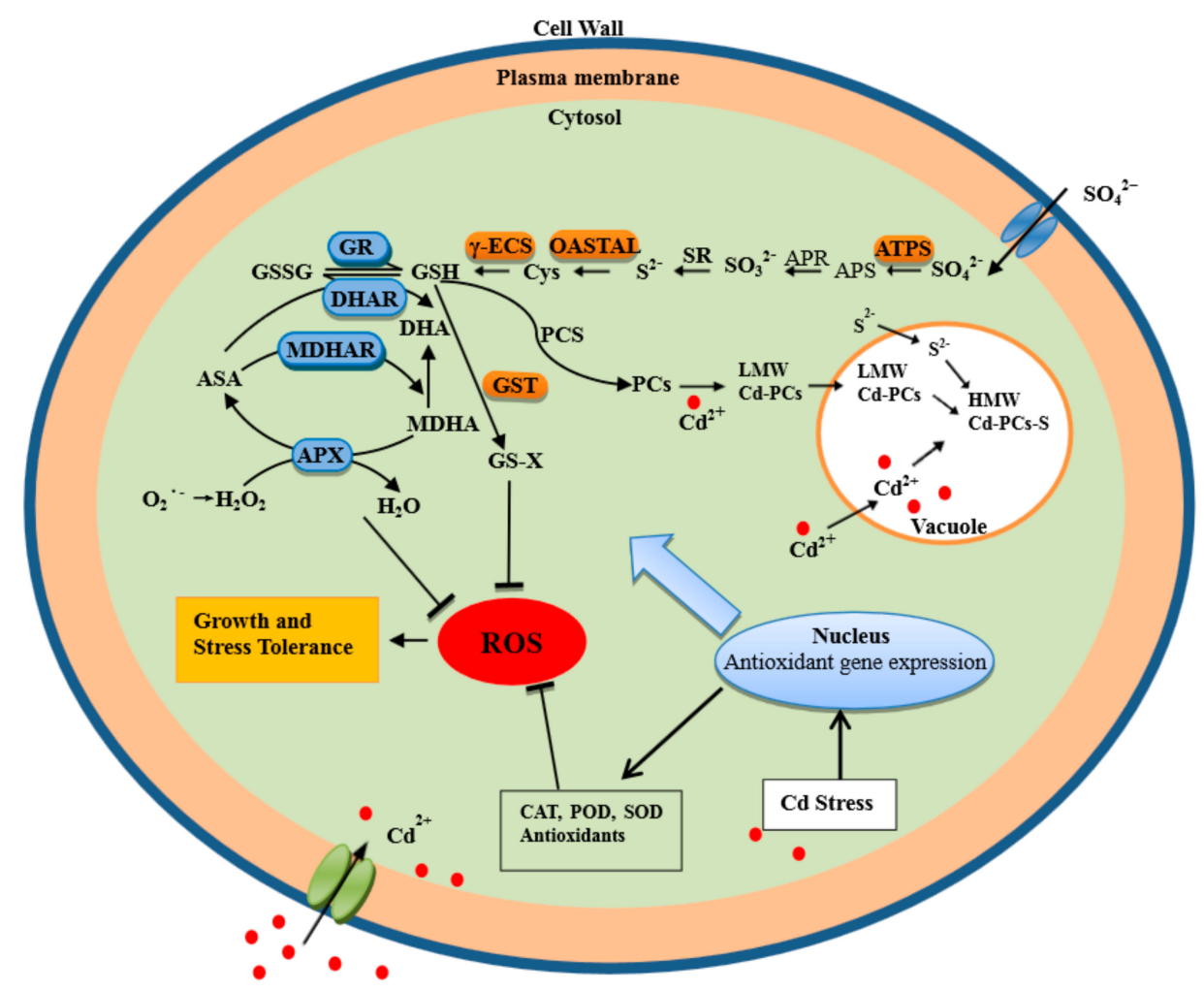

Figure 9. Simplified metabolic scheme and signal transduction pathway for the role of sulfur in regulating $\mathrm{Cd}$ accumulation and tolerance. 


\section{Materials and Methods}

\subsection{Plant Cultivation}

A pot culture experiment was conducted from June to October 2015 under open field conditions in the Northwest A\&F University, Yangling, Shaanxi, China ( $34^{\circ} 22^{\prime} \mathrm{N}, 108^{\circ} 26^{\prime} \mathrm{E}, 526 \mathrm{~m}$ elevation). Surface soil $(0-30 \mathrm{~cm})$ was collected from the local agricultural farm (earth-cumuli-orthic anthrosols). Surface soil was passed through a $5 \mathrm{~mm}$ sieve. Then, $2.5 \mathrm{~kg}$ soil samples were filled with each plastic pot (20 cm in diameter and $15 \mathrm{~cm}$ in height) after being artificially mixed with $\mathrm{Cd}$ (in $\mathrm{CdCl}_{2} \cdot 2.5 \mathrm{H}_{2} \mathrm{O}$ solution) and $\mathrm{S}$ (in $\mathrm{Na}_{2} \mathrm{SO}_{4}$ solution). Since $\mathrm{Na}_{2} \mathrm{SO}_{4}$ is the only source of sulfur, the amount of $\mathrm{NaCl}$ was simultaneously increased to restore standard sodium concentration in sulfate-deprived treatment. Six treatments including the control (without addition of $\mathrm{Cd}$ and $\mathrm{S}$ ) were arranged and applied according to the following treatments:

(1) Control (CK), $0 \mathrm{mg} \cdot \mathrm{kg}^{-1} \mathrm{CdCl}_{2} \cdot 2.5 \mathrm{H}_{2} \mathrm{O}+0 \mathrm{mg} \cdot \mathrm{kg}^{-1} \mathrm{Na}_{2} \mathrm{SO}_{4}$;

(2) $\mathrm{Cd} 1,1 \mathrm{mg} \cdot \mathrm{kg}^{-1} \mathrm{CdCl}_{2} \cdot 2.5 \mathrm{H}_{2} \mathrm{O}+0 \mathrm{mg} \cdot \mathrm{kg}^{-1} \mathrm{Na}_{2} \mathrm{SO}_{4}$;

(3) $\mathrm{Cd} 10,10 \mathrm{mg} \cdot \mathrm{kg}^{-1} \mathrm{CdCl}_{2} \cdot 2.5 \mathrm{H}_{2} \mathrm{O}+0 \mathrm{mg} \cdot \mathrm{kg}^{-1} \mathrm{Na}_{2} \mathrm{SO}_{4}$;

(4) $\mathrm{S}, 0 \mathrm{mg} \cdot \mathrm{kg}^{-1} \mathrm{CdCl}_{2} \cdot 2.5 \mathrm{H}_{2} \mathrm{O}+50 \mathrm{mg} \cdot \mathrm{kg}^{-1} \mathrm{Na}_{2} \mathrm{SO}_{4}$;

(5) $\mathrm{Cd} 1+\mathrm{S}, 1 \mathrm{mg} \cdot \mathrm{kg}^{-1} \mathrm{CdCl}_{2} \cdot 2.5 \mathrm{H}_{2} \mathrm{O}+50 \mathrm{mg} \cdot \mathrm{kg}^{-1} \mathrm{Na}_{2} \mathrm{SO}_{4}$;

(6) $\mathrm{Cd} 10+\mathrm{S}, 10 \mathrm{mg} \cdot \mathrm{kg}^{-1} \mathrm{CdCl}_{2} \cdot 2.5 \mathrm{H}_{2} \mathrm{O}+50 \mathrm{mg} \cdot \mathrm{kg}^{-1} \mathrm{Na}_{2} \mathrm{SO}_{4}$.

The soil subsamples were fully watered and then left for equilibration outdoors for approximately 60 days.

After 60 days, two identified Pakchoi genotypes, namely, Aikangqing (a Cd-tolerant cultivar) and Qibaoqing (a Cd-sensitive cultivar) were used in the present study. In each pot, 10 seeds were sown directly into the soil, and the number of seedlings were reduced to 5 per pot after two weeks. Four replicates were used for each treatment. The plants were grown for 40 days, and then harvested for analysis.

\subsection{Measurement of Morphological Features}

Five plants from four separate pots of each treatment were used as biological replicates after 40 days of growth. The roots and shoots with same sizes were harvested and rinsed with tap water to remove soil. The roots were dipped in $10 \mathrm{mM}$ ethylenediaminetetraacetic acid (EDTA) for $10 \mathrm{~min}$, and then rinsed thoroughly with distilled water. The plants into roots and shoots were separated. Fresh shoot and root samples were frozen in liquid nitrogen $\left(\mathrm{N}_{2}\right)$ and stored at $-80{ }^{\circ} \mathrm{C}$ until further physiological and biochemical analyses.

Morphological growth parameters, such as root fresh weight, root length, root dry weight, shoot fresh weight, shoot height, and shoot dry weight were measured.

The roots and shoots of the plants were separated manually, and then dried at $80^{\circ} \mathrm{C}$ in an oven to a constant weight before obtaining the dry weight. The dried plant tissues were prepared for Cd measurement.

The collected soil samples were dried and sieved through a $2 \mathrm{~mm}$ sieve.

\subsection{Cd Determination by Atomic Absorption Spectroscopy}

The dried shoots, roots, and soil samples were ground. The resulting powder (approximately $0.2 \mathrm{~g})$ was used for digestion with a $10 \mathrm{~mL}$ solution of $\mathrm{HNO}_{3}$ and $\mathrm{HClO}_{4}(v / v=4: 1)$ at $220{ }^{\circ} \mathrm{C}$. Cd concentration was measured through flame atomic absorption spectroscopy (Hitachi 180-80, Japan).

\subsection{Bioconcentration and Translocation Factors}

The bioconcentration factor (BCF) is defined as an excellent index of metal accumulation capacitance in plants. The translocation factor (TF) can be used to evaluate a plant's potential for 
phytoremediation purpose. The BCF and TF were calculated following methods of Shi and Cai [56], as follows:

$$
\begin{gathered}
\mathrm{BCF}=\mathrm{Cd}_{\text {shoot or root }} / \mathrm{Cd}_{\text {soil }}, \\
\mathrm{TF}=\mathrm{Cd}_{\text {shoot }} / \mathrm{Cd}_{\text {root}},
\end{gathered}
$$

where $\mathrm{Cd}_{\text {soil }}$ is the concentration of total $\mathrm{Cd}$ in soil; $\mathrm{Cd}_{\text {shoot }}$ and $\mathrm{Cd}_{\text {root }}$ are the concentration of $\mathrm{Cd}$ in the shoot and root parts, respectively.

\subsection{Measurement of Malondialdehyde (MDA) and Hydrogen Peroxide $\left(\mathrm{H}_{2} \mathrm{O}_{2}\right)$ Content}

MDA content was measured by using 2-thiobarbituric acid reactions, and the results were analyzed spectrophotometrically at 450,532 , and $600 \mathrm{~nm}$ as described by Hodges et al. [85]. The $\mathrm{H}_{2} \mathrm{O}_{2}$ content was analyzed as described by Alexieva et al. [86].

\subsection{Activity of Enzymes of S Assimilation Pathway and ASA-GSH Cycle Metabolism}

The method of Masato [87] with some modifications was used to determine the reduced ASA and oxidized DHA ascorbate contents. Total GSH and GSSG were measured following the method of Anderson [88].

Total NPT were measured following the method of Ellman [89]. PC content was calculated according to the method of Duan et al. [90]. The latter method subtracts the GSH content from that of the NPT (PCs = NPT - total GSH).

APX activity (EC 1.11.1.11) was measured by monitoring the change in absorbance at $290 \mathrm{~nm}$, and GR (EC 1.6.4.2) was monitored at $340 \mathrm{~nm}$ following the method of Nakano and Asada [91] and Smith et al. [92].

Up to $0.5 \mathrm{~g}$ plant samples were extracted in $5 \mathrm{~mL}$ medium containing $50 \mathrm{mM}$ phosphate buffer, pH 7.5, $1 \mathrm{mM}$ EDTA, and $1 \mathrm{mM}$ dithiothreitol to estimate GST (EC 2.5.1.18) activity. The enzyme activity was assayed in a reaction mixture containing $100 \mathrm{mM}$ potassium phosphate buffer ( $\mathrm{pH}$ 6.5), $1 \mathrm{mM}$ EDTA, $1 \mathrm{mM}$ 1-chloro-2, 4-dinitrobenzene, $1 \mathrm{mM} \mathrm{GSH}$, and the enzyme extract. The increase in absorbance was determined at $340 \mathrm{~nm}$. The activity was calculated using an extinction coefficient of $9.6 \mathrm{mM} \cdot \mathrm{cm}^{-1}$ expressed as U. $\mathrm{min}^{-1} \mathrm{mg} \cdot$ protein $^{-1}$ [93].

ATP sulfurylase (ATPS, EC 2.7.7.4) activity was assayed using molybdate-dependent formation of pyrophosphate as described by the method of Lappartient and Touraine [94]. O-acetylserine(thiol)lyase (EC 4.2.99.8) was measured according to the method by Riemenschneider et al. [95]. Assays for $\gamma$-ECS (EC 6.3.2.2) activities and the method according to Seelig and Meister (1984) were performed with slight modifications. Enzyme activity was presented as $\mu \mathrm{mol} \mathrm{Pi} / \mathrm{min} \mathrm{mg}$ protein.

DHAR (EC 1.8.5.1) activity was measured at $265 \mathrm{~nm}$ following the method of Pinto et al. [96]. In this method, the GSH-dependent production of ASA is determined. The enzyme extract was added to a reaction mixture containing $50 \mathrm{mM}$ phosphate buffer ( $\mathrm{pH} 7.0$ ), $20 \mathrm{mM} \mathrm{GSH}$, and $2 \mathrm{mM}$ DHA. The reaction was initiated by adding DHA. One unit of DHAR activity was defined as a 0.01 increase in absorbance at $265 \mathrm{~nm}$ for $1 \mathrm{~min}$.

MDHAR (EC 1.6.5.4) activity was determined following the method of (Pinto,TommasiandGara [96]) with slight modifications. The reaction mixture contained $50 \mathrm{mM}$ phosphate buffer ( $\mathrm{pH}$ 7.0), $2 \mathrm{mM}$ ASA, $0.25 \mathrm{U}$ AAO, $2 \mathrm{mM} \mathrm{NADPH}$, and enzyme extract. The reaction was initiated by adding AAO. One unit of MDHAR activity was defined as a 0.01 increase in absorbance at $290 \mathrm{~nm}$ for $1 \mathrm{~min}$.

\subsection{RNA Extraction and Quantitative Real-Time Polymerase Chain Reaction}

Total RNAs of the shoots and roots were extracted from the samples of the three independent biological replicates for each of genotypes using the TRIzol reagent (Invitrogen) according to the manufacturer's instructions. The first strand of cDNA was synthesized using $1.0 \mu \mathrm{g}$ total RNA, $0.5 \mu \mathrm{g}$ oligo d (T) 18 primer, and reverse transcriptase system (DRR037A; Takara, Dalian, China) at a total volume of $20 \mu \mathrm{L}$. The primers used for $\mathrm{qPCR}$ were designed according to the corresponding 
sequence on Primer 6, and the primers are listed in Table S1. Amplification through quantitative real-time polymerase chain reaction was performed with a Thermal Cycler Dice Real Time System III (Takarabio Inc., Otsu, Shiga, Japan) using an RT-PCR master mix (DRR820A; Takara) according to the user manual. The expression levels of the target genes were normalized using actin as an endogenous control. All reactions were run in triplicate. The quantification of gene expression levels relative to the control was determined by $2^{-\Delta \Delta C t}$ method.

\subsection{Statistical Analysis}

All the results presented were the mean values of three replications. All data were expressed as means \pm standard deviation (SD). The one-way analysis of variance was performed by SPSS software version 19 (SPSS Inc., Chicago, IL, USA). Significant differences from the control values were determined at $p<0.05$.

\section{Conclusions}

In this current study, morpho-physiological findings support that sulfur plays a critical role to withstand $\mathrm{Cd}$ toxicity and to restore the normal growth and development in Pakchoi plants. Decreased Cd uptake and translocation, as well as improved compartmentation, readjustment of redox homeostasis, and strengthened antioxidant capacity by further upregulating key enzyme genes as indicated by elevated ascorbate levels contribute to the $\mathrm{S}$ effect. These findings showed that Pakchoi plants adjust their response to excess $\mathrm{Cd}$ by $\mathrm{S}$ nutrient supplementation, including the elaborated regulation of $\mathrm{Cd}$ distribution and ROS elimination. Magnitude of $\mathrm{Cd}$ induced toxicity was low in Aikangqing, which correlated strongly with effective ASA-GSH cycle and strong defense response. $\mathrm{S}$ as a nutrient element can be used in agricultural production to reduce $\mathrm{Cd}$ toxicity and increase sustainability. These results may stimulate further studies via enhancing soil fertility and ameliorating the contaminated soil to achieve breeding of low $\mathrm{Cd}$ accumulating cultivars for Pakchoi plants.

Supplementary Materials: Supplementary materials can be found at www.mdpi.com/1422-0067/18/8/1628/s1.

Acknowledgments: This research was financially supported by the National Natural Science Foundation of China (No. 31271624) and Agricultural Science and Technology Innovation of Shaanxi Province Key Project (China, 2016NY-135).

Author Contributions: Lili Lou and Jinyin Lv conceived and designed the experiments; Lili Lou performed the experiments; Jingquan Kang, Hongxi Pang, Xiaoping Du, Qiuyu Li, Wei Wu and Junxiu Chen helped in plant sampling and data analyses; Lili Lou wrote the paper. All of the authors discussed the results and commented on the manuscript.

Conflicts of Interest: The authors declare no conflict of interest. The founding sponsors had no role in the design of the study; in the collection, analyses, or interpretation of data; in the writing of the manuscript, and in the decision to publish the results.

\section{Abbreviations}

$\begin{array}{ll}\text { Cd } & \text { cadmium } \\ \text { S } & \text { sulfur } \\ \text { ASA } & \text { ascorbate } \\ \text { GSH } & \text { glutathione } \\ \text { PCs } & \text { phytochelatins } \\ \text { NPT } & \text { nonprotein thiol } \\ \text { ROS } & \text { reactive oxygen species } \\ \text { APX } & \text { ascorbate peroxidase } \\ \text { GR } & \text { glutathione reductase } \\ \text { DHAR } & \text { dehydroascorbate reductase } \\ \text { MDHAR } & \text { monodehydroascorbate reductase } \\ \text { GSSG } & \text { oxidized glutathione } \\ \text { DHA } & \text { dehydroascorbate }\end{array}$




$\begin{array}{ll}\text { GST } & \text { glutathione-S-transferases } \\ \text { ATPS } & \text { ATP sulfurylase } \\ \text { OASTAL } & \text { O-acetylserine(thiol)lyase } \\ \gamma \text {-ECS } & \gamma \text {-glutamylcysteine synthetase } \\ \mathrm{H}_{2} \mathrm{O}_{2} & \text { hydrogen peroxide } \\ \mathrm{MDA} & \text { malondialdehyde } \\ \text { BCF } & \text { bioconcentration factor } \\ \text { TF } & \text { translocation factor }\end{array}$

\section{References}

1. Chen, J.; Yang, L.; Gu, J.; Bai, X.; Ren, Y.; Fan, T.; Han, Y.; Jiang, L.; Xiao, F.; Liu, Y. Man3 gene regulates cadmium tolerance through the glutathione-dependent pathway in arabidopsis thaliana. New Phytol. 2015, 205, 570-582. [CrossRef]

2. Lin, Y.F.; Aarts, M.G.M. The molecular mechanism of zinc and cadmium stress response in plants. Cell. Mol. Life Sci. 2012, 69, 3187-3206. [CrossRef]

3. Singh, S.; Parihar, P.; Singh, R.; Singh, V.P.; Prasad, S.M. Heavy metal tolerance in plants: Role of transcriptomics, proteomics, metabolomics, and ionomics. Front. Plant Sci. 2015, 6, 1143. [CrossRef]

4. Tripathi, R.D.; Tripathi, P.; Dwivedi, S.; Dubey, S.; Chatterjee, S.; Chakrabarty, D.; Trivedi, P.K. Arsenomics: Omics of arsenic metabolism in plants. Front. Physiol. 2012, 3, 275. [CrossRef] [PubMed]

5. Benavides, M.P.; Gallego, S.M.; Tomaro, M.L. Cadmium toxicity in plants. Braz. J. Plant Physiol. 2005, 17, 21-34. [CrossRef]

6. Shim, D.; Hwang, J.U.; Lee, J.; Lee, S.; Choi, Y.; An, G.; Martinoia, E.; Lee, Y. Orthologs of the class a4 heat shock transcription factor HsfA4a confer cadmium tolerance in wheat and rice. Plant Cell 2009, 21, 4031-4043. [CrossRef]

7. Clemens, S.; Ma, J.F. Toxic heavy metal and metalloid accumulation in crop plants and foods. Annu. Rev. Plant Biol. 2016, 67, 489-512. [CrossRef] [PubMed]

8. Roth, U.; von Roepenack-Lahaye, E.; Clemens, S. Proteome changes in arabidopsis thaliana roots upon exposure to $\mathrm{CD}^{2+}$. J. Exp. Bot. 2006, 57, 4003-4013. [CrossRef] [PubMed]

9. Djebali, W.; Gallusci, P.; Polge, C.; Boulila, L.; Galtier, N.; Raymond, P.; Chaibi, W.; Brouquisse, R. Modifications in endopeptidase and $20 \mathrm{~s}$ proteasome expression and activities in cadmium treated tomato (Solanum lycopersicum L.) plants. Planta 2008, 227, 625-639. [CrossRef]

10. Iqbal, N.; Khan, N.A. Variation in growth, photosynthesis functions and yield of five mustard (Brassica juncea L.) cultivars under high cadmium stress. Plant Stress 2010, 4, 87-93.

11. Foyer, C.H.; Noctor, G. Redox homeostasis and antioxidant signaling: A metabolic interface between stress perception and physiological responses. Plant Cell 2005, 17, 1866-1875. [CrossRef] [PubMed]

12. Anjum, N.A.; Umar, S.; Ahmad, A.; Iqbal, M.; Khan, N.A. Ontogenic variation in response of Brassica campestris L. To cadmium toxicity. J. Plant Interact. 2008, 3, 189-198. [CrossRef]

13. Sandalio, L.M.; Dalurzo, H.C.; Gómez, M.; Romero-Puertas, M.C.; Río, L.A.D. Cadmium-induced changes in the growth and oxidative metabolism of pea plants. J. Exp. Bot. 2001, 52, 2115-2126. [CrossRef] [PubMed]

14. Liu, J.; Ma, J.; He, C.; Li, X.; Zhang, W.; Xu, F.; Lin, Y.; Wang, L. Inhibition of cadmium ion uptake in rice (Oryza sativa L.) cells by a wall-bound form of silicon. New Phytol. 2013, 200, 691-699. [CrossRef] [PubMed]

15. Meyer, C.L.; Juraniec, M.; Huguet, S.; Chaves-Rodriguez, E.; Salis, P.; Isaure, M.P.; Goormaghtigh, E.; Verbruggen, N. Intraspecific variability of cadmium tolerance and accumulation, and cadmium-induced cell wall modifications in the metal hyperaccumulator Arabidopsis halleri. J. Exp. Bot. 2015, 66, 3215-3227. [CrossRef] [PubMed]

16. Xing, J.P.; Jiang, R.F.; Ueno, D.; Ma, J.F.; Schat, H.; McGrath, S.P.; Zhao, F.J. Variation in root-to-shoot translocation of cadmium and zinc among different accessions of the hyperaccumulators thlaspi caerulescens and thlaspi praecox. New Phytol. 2008, 178, 315-325. [CrossRef] [PubMed]

17. Lindberg, S.; Landberg, T.; Greger, M. Cadmium uptake and interaction with phytochelatins in wheat protoplasts. Plant Physiol. Biochem. 2007, 45, 47-53. [CrossRef] [PubMed]

18. Greger, M.; Kabir, A.H.; Landberg, T.; Maity, P.J.; Lindberg, S. Silicate reduces cadmium uptake into cells of wheat. Environ. Pollut. 2015, 211, 90-97. [CrossRef] [PubMed] 
19. Cobbett, C.S. Phytochelatins and their roles in heavy metal detoxification. Plant Physiol. 2000, 123, 825-832. [CrossRef] [PubMed]

20. Hall, J.L. Cellular mechanisms for heavy metal detoxification and tolerance. J. Exp. Bot. 2002, 53, 1-11. [CrossRef] [PubMed]

21. Bashri, G.; Prasad, S.M. Exogenous IAA differentially affects growth, oxidative stress and antioxidants system in cd stressed Trigonella foenum-graecum L. Seedlings: Toxicity alleviation by up-regulation of ascorbate-glutathione cycle. Ecotoxicol. Environ. Saf. 2016, 132, 329-338. [CrossRef] [PubMed]

22. Singh, V.P.; Singh, S.; Kumar, J.; Prasad, S.M. Investigating the roles of ascorbate-glutathione cycle and thiol metabolism in arsenate tolerance in ridged luffa seedlings. Protoplasma 2015, 252, 1217-1229. [CrossRef] [PubMed]

23. Capaldi, F.R.; Gratão, P.L.; Reis, A.R.; Lima, L.W.; Azevedo, R.A. Sulfur metabolism and stress defense responses in plants. Trop. Plant Biol. 2015, 8, 60-73. [CrossRef]

24. Noctor, G.; Foyer, C.H. Ascorbate and glutathione: Keeping active oxygen under control. Plant Biol. 1998, 49, 249-279. [CrossRef] [PubMed]

25. Shigeoka, S.; Ishikawa, T.; Tamoi, M.; Miyagawa, Y.; Takeda, T.; Yabuta, Y.; Yoshimura, K. Regulation and function of ascorbate peroxidase isoenzymes. J. Exp. Bot. 2002, 53, 1305-1319. [CrossRef] [PubMed]

26. Rao, A.C.; Reddy, A.R. Glutathione reductase: A putative redox regulatory system in plant cells. In Sulfur Assimilation and Abiotic Stress in Plants; Springer: Berlin/Heidelberg, Germany, 2008; pp. 111-147.

27. Liu, S.; Liu, S.; Wang, M.; Wei, T.; Meng, C.; Wang, M.; Xia, G. A wheat similar to rcd-one gene enhances seedling growth and abiotic stress resistance by modulating redox homeostasis and maintaining genomic integrity. Plant Cell 2014, 26, 164-180. [CrossRef] [PubMed]

28. Gill, S.S.; Anjum, N.A.; Hasanuzzaman, M.; Gill, R.; Trivedi, D.K.; Ahmad, I.; Pereira, E.; Tuteja, N. Glutathione and glutathione reductase: A boon in disguise for plant abiotic stress defense operations. Plant Physiol. Biochem. 2013, 70, 204-212. [CrossRef] [PubMed]

29. Han, D.; Xiong, S.; Tu, S.; Liu, J.; Chen, C. Interactive effects of selenium and arsenic on growth, antioxidant system, arsenic and selenium species of Nicotiana tabacum L. Environ. Exp. Bot. 2015, 117, 12-19. [CrossRef]

30. Nazar, R.; Iqbal, N.; Masood, A.; Khan, M.I.R.; Syeed, S.; Khan, N.A. Cadmium toxicity in plants and role of mineral nutrients in its alleviation. Am. J. Plant Sci. 2012, 3, 1476-1489. [CrossRef]

31. Sarwar, N.; Saifullah; Malhi, S.S.; Zia, M.H.; Naeem, A.; Bibi, S.; Farid, G. Role of mineral nutrition in minimizing cadmium accumulation by plants. J. Sci. Food Agric. 2010, 90, 925-937. [PubMed]

32. Uraguchi, S.; Watanabe, I.; Yoshitomi, A.; Kiyono, M.; Kuno, K. Characteristics of cadmium accumulation and tolerance in novel cd-accumulating crops, Avena strigosa and Crotalaria juncea. J. Exp. Bot. 2006, 57, 2955-2965. [CrossRef] [PubMed]

33. Farshidi, M.; Abdolzadeh, A.; Sadeghipour, H.R. Silicon nutrition alleviates physiological disorders imposed by salinity in hydroponically grown canola (Brassica napus L.) plants. J. Acta Physiol. Plant. 2012, 34, 1779-1788. [CrossRef]

34. Dixit, G.; Singh, A.P.; Kumar, A.; Mishra, S.; Dwivedi, S.; Kumar, S.; Trivedi, P.K.; Pandey, V.; Tripathi, R.D. Reduced arsenic accumulation in rice (Oryza sativa L.) shoot involves sulfur mediated improved thiol metabolism, antioxidant system and altered arsenic transporters. Plant Physiol. Biochem. 2016, 99, 86-96. [CrossRef] [PubMed]

35. Astolfi, S.; Zuchi, S.; Neumann, G.; Cesco, S.; Sanità, D.T.L.; Pinton, R. Response of barley plants to fe deficiency and cd contamination as affected by s starvation. J. Exp. Bot. 2012, 63, 1241. [CrossRef] [PubMed]

36. Saito, K. Sulfur assimilatory metabolism. The long and smelling road. Plant Physiol. 2004, 136, $2443-2450$. [CrossRef] [PubMed]

37. Noctor, G.; Mhamdi, A.; Chaouch, S.; Han, Y.; Neukermans, J.; Marquez-Garcia, B.; Queval, G.; Foyer, C.H. Glutathione in plants: An integrated overview. Plant Cell Environ. 2011, 35, 454-484. [CrossRef] [PubMed]

38. He, J.; Li, H.; Ma, C.; Zhang, Y.; Polle, A.; Rennenberg, H.; Cheng, X.; Luo, Z.B. Overexpression of bacterial gamma-glutamylcysteine synthetase mediates changes in cadmium influx, allocation and detoxification in poplar. New Phytol. 2015, 205, 240-254. [CrossRef] [PubMed]

39. Anjum, N.A.; Gill, R.; Kaushik, M.; Hasanuzzaman, M.; Pereira, E.; Ahmad, I.; Tuteja, N.; Gill, S.S. Atp-sulfurylase, sulfur-compounds, and plant stress tolerance. Front. Plant Sci. 2015, 6, 210. [CrossRef] [PubMed] 
40. Dhankher, O.P.; Li, Y.; Rosen, B.P.; Shi, J.; Salt, D.; Senecoff, J.F.; Sashti, N.A.; Meagher, R.B. Engineering tolerance and hyperaccumulation of arsenic in plants by combining arsenate reductase and $\gamma$-glutamylcysteine synthetase expression. Nat. Biotechnol. 2002, 20, 1140-1145. [CrossRef] [PubMed]

41. Zhou, Q.; Guo, J.J.; He, C.T.; Shen, C.; Huang, Y.Y.; Chen, J.X.; Guo, J.H.; Yuan, J.G.; Yang, Z.Y. Comparative transcriptome analysis between low- and high-cadmium-accumulating genotypes of pakchoi (Brassica chinensis L.) in response to cadmium stress. Environ. Sci. Technol. 2016, 50, 6485-6494. [CrossRef] [PubMed]

42. Sun, F.; Yang, X.; Li, Y.; Hou, X. Molecular cloning and characterisation of cytoplasmic glutamine synthetase gene bcgs1 from non-heading chinese cabbage. J. Sci. Food Agric. 2010, 90, 891-897. [PubMed]

43. Yan, S.; Ling, Q.; Bao, Z.; Chen, Z.; Yan, S.; Dong, Z.; Zhang, B.; Deng, B. Cadmium accumulation in pak choi (Brassica chinensis L.) and estimated dietary intake in the suburb of hangzhou city, China. Food Addit. Contam. Part B Surveill. 2009, 2, 74-78. [CrossRef] [PubMed]

44. Chen, Y.; Li, T.Q.; Han, X.; Ding, Z.L.; Yang, X.E.; Jin, Y.F. Cadmium accumulation in different pakchoi cultivars and screening for pollution-safe cultivars. J. Zhejiang Univ. Sci. B 2012, 13, 494-502. [CrossRef] [PubMed]

45. Gill, S.S.; Tuteja, N. Cadmium stress tolerance in crop plants: Probing the role of sulfur. Plant Signal. Behav. 2011, 6, 215-222. [CrossRef] [PubMed]

46. Astolfi, S.; Ortolani, M.R.; Catarcione, G.; Paolacci, A.R.; Cesco, S.; Pinton, R.; Ciaffi, M. Cadmium exposure affects iron acquisition in barley (Hordeum vulgare) seedlings. Physiol. Plant. 2014, 152, 646-659. [CrossRef] [PubMed]

47. Gill, S.S.; Khan, N.A.; Tuteja, N. Cadmium at high dose perturbs growth, photosynthesis and nitrogen metabolism while at low dose it up regulates sulfur assimilation and antioxidant machinery in garden cress (Lepidium sativum L.). Plant Sci. Int. J. Exp. Plant Biol. 2012, 182, 112-120. [CrossRef] [PubMed]

48. Khan, N.A.; Singh, S.; Nazar, R. Activities of antioxidative enzymes, sulphur assimilation, photosynthetic activity and growth of wheat (Triticum aestivum) cultivars differing in yield potential under cadmium stress. J. Agron. Crop Sci. 2007, 193, 435-444. [CrossRef]

49. Akesson, A.; Barregard, L.; Bergdahl, I.A.; Nordberg, G.F.; Nordberg, M.; Skerfving, S. Non-renal effects and the risk assessment of environmental cadmium exposure. Environ. Health Perspect. 2014, 122, 431-438. [CrossRef] [PubMed]

50. Matraszek, R.; Hawrylak-Nowak, B.; Chwil, S.; Chwil, M. Macroelemental composition of cadmium stressed lettuce plants grown under conditions of intensive sulphur nutrition. J. Environ. Manag. 2016, 180, $24-34$. [CrossRef] [PubMed]

51. Sheng, H.; Zeng, J.; Liu, Y.; Wang, X.; Wang, Y.; Kang, H.; Fan, X.; Sha, L.; Zhang, H.; Zhou, Y. Sulfur mediated alleviation of $\mathrm{mn}$ toxicity in polish wheat relates to regulating $\mathrm{mn}$ allocation and improving antioxidant system. Front. Plant Sci. 2016, 7, 1382. [CrossRef] [PubMed]

52. Foyer, C.H.; Noctor, G. Ascorbate and glutathione: The heart of the redox hub. Plant Physiol. 2011, 155, 2-18. [CrossRef] [PubMed]

53. Krantev, A.; Yordanova, R.; Janda, T.; Szalai, G.; Popova, L. Treatment with salicylic acid decreases the effect of cadmium on photosynthesis in maize plants. J. Plant Physiol. 2008, 165, 920-931. [CrossRef] [PubMed]

54. Dixit, G.; Singh, A.P.; Kumar, A.; Singh, P.K.; Kumar, S.; Dwivedi, S.; Trivedi, P.K.; Pandey, V.; Norton, G.J.; Dhankher, O.P.; et al. Sulfur mediated reduction of arsenic toxicity involves efficient thiol metabolism and the antioxidant defense system in rice. J. Hazard. Mater. 2015, 298, 241-251. [CrossRef] [PubMed]

55. Anjum, N.A.; Umar, S.; Ahmad, A.; Iqbal, M.; Khan, N.A. Sulphur protects mustard (Brassica campestris L.) from cadmium toxicity by improving leaf ascorbate and glutathione. Plant Growth Regul. 2008, 54, 271-279. [CrossRef]

56. Shi, G.; Cai, Q. Cadmium tolerance and accumulation in eight potential energy crops. Biotechnol. Adv. 2009, 27, 555-561. [CrossRef] [PubMed]

57. Ding, H.; Wang, G.; Lou, L.; Lv, J. Physiological responses and tolerance of kenaf (Hibiscus cannabinus L.) exposed to chromium. Ecotoxicol. Environ. Saf. 2016, 133, 509-518. [CrossRef] [PubMed]

58. Odjegba, V.; Fasidi, I. Accumulation of trace elements by pistia stratiotes: Implications for phytoremediation. Ecotoxicology 2004, 13, 637-646. [CrossRef] [PubMed]

59. Zayed, A.; Gowthaman, S.; Terry, N. Phytoaccumulation of trace elements by wetland plants: I. Duckweed. J. Environ. Qual. 1998, 27, 715-721. [CrossRef] 
60. Fotopoulos, V.; Ziogas, V.; Tanou, G.; Molassiotis, A. Involvement of asa/dha and gsh/gssg ratios in gene and protein expression and in the activation of defence mechanisms under abiotic stress conditions. In Ascorbate-Glutathione Pathway and Stress Tolerance in Plants; Springer: Dordrecht, The Netherlands, 2010; pp. 265-302.

61. Dietz, K.J.; Mittler, R.; Noctor, G. Recent progress in understanding the role of reactive oxygen species in plant cell signaling. Plant Physiol. 2016, 171, 1535-1539. [CrossRef] [PubMed]

62. Baxter, A.; Mittler, R.; Suzuki, N. Ros as key players in plant stress signalling. J. Exp. Bot. 2014, 65, 1229-1240. [CrossRef] [PubMed]

63. Gill, S.S.; Tuteja, N. Reactive oxygen species and antioxidant machinery in abiotic stress tolerance in crop plants. Plant Physiol. Biochem. 2010, 48, 909-930. [CrossRef] [PubMed]

64. Han, Y.; Zhang, J.; Chen, X.; Gao, Z.; Xuan, W.; Xu, S.; Ding, X.; Shen, W. Carbon monoxide alleviates cadmium-induced oxidative damage by modulating glutathione metabolism in the roots of Medicago sativa. New Phytol. 2007, 177, 155-166. [CrossRef] [PubMed]

65. Gupta, D.K.; Palma, J.M.; Corpas, F.J. Reactive Oxygen Species and Oxidative Damage in Plants Under Stress; Springer International Publishing: Berlin/Heidelberg, Germany, 2015; p. 621.

66. Wei, L.; Wang, L.; Yang, Y.; Wang, P.; Guo, T.; Kang, G. Abscisic acid enhances tolerance of wheat seedlings to drought and regulates transcript levels of genes encoding ascorbate-glutathione biosynthesis. Front. Plant Sci. 2015, 6, 458. [CrossRef] [PubMed]

67. Song, L.; Wang, J.; Shafi, M.; Liu, Y.; Wang, J.; Wu, J.; Wu, A. Hypobaric treatment effects on chilling injury, mitochondrial dysfunction, and the ascorbate-glutathione (ASA-GSH) cycle in postharvest peach fruit. J. Agric. Food Chem. 2016, 64, 4665-4674. [CrossRef] [PubMed]

68. Khan, M.I.; Khan, N.A.; Masood, A.; Per, T.S.; Asgher, M. Hydrogen peroxide alleviates nickel-inhibited photosynthetic responses through increase in use-efficiency of nitrogen and sulfur, and glutathione production in mustard. Front. Plant Sci. 2016, 7, 44. [CrossRef] [PubMed]

69. Shu, S.; Gao, P.; Li, L.; Yuan, Y.; Sun, J.; Guo, S. Abscisic acid-induced $\mathrm{H}_{2} \mathrm{O}_{2}$ accumulation enhances antioxidant capacity in pumpkin-grafted cucumber leaves under $\mathrm{Ca}\left(\mathrm{NO}_{3}\right)_{2}$ stress. Front. Plant Sci. 2016, 7, 1489. [CrossRef] [PubMed]

70. Bashir, H.; Ibrahim, M.M.; Bagheri, R.; Ahmad, J.; Arif, I.A.; Baig, M.A.; Qureshi, M.I. Influence of sulfur and cadmium on antioxidants, phytochelatins and growth in indian mustard. AoB Plants 2015. [CrossRef] [PubMed]

71. Astolfi, S.; Zuchi, S.; Passera, C. Role of sulphur availability on cadmium-induced changes of nitrogen and sulphur metabolism in maize (Zea mays L.) leaves. J. Plant Physiol. 2004, 161, 795-802. [CrossRef] [PubMed]

72. Wu, Z.; Zhang, C.; Dai, C.; Ge, Y. Sufficient sulfur supply promotes seedling growth, alleviates oxidation stress, and regulates iron uptake and translocation in rice. Biol. Plant. 2015, 59, 788-792. [CrossRef]

73. Matraszek, R.; Hawrylak-Nowak, B.; Chwil, S.; Chwil, M. Interaction between cadmium stress and sulphur nutrition level on macronutrient status of Sinapis alba L. Water Air Soil Pollut. 2016, 227, 355. [CrossRef] [PubMed]

74. Anjum, N.A.; Umar, S.; Iqbal, M.; Khan, N.A. Cadmium causes oxidative stress in mung bean by affecting the antioxidant enzyme system and ascorbate-glutathione cycle metabolism. Russ. J. Plant Physiol. 2011, 58, 92-99. [CrossRef]

75. Nocito, F.F.; Lancilli, C.; Crema, B.; Fourcroy, P.; Davidian, J.C.; Sacchi, G.A. Heavy metal stress and sulfate uptake in maize roots. Plant Physiol. 2006, 141, 1138-1148. [CrossRef] [PubMed]

76. Brunetti, P.; Zanella, L.; De Paolis, A.; Di Litta, D.; Cecchetti, V.; Falasca, G.; Barbieri, M.; Altamura, M.M.; Costantino, P.; Cardarelli, M. Cadmium-inducible expression of the ABC-type transporter AtABCC3 increases phytochelatin-mediated cadmium tolerance in Arabidopsis. J. Exp. Bot. 2015, 66, 3815-3829. [CrossRef] [PubMed]

77. Chen, J.; Yang, L.; Yan, X.; Liu, Y.; Wang, R.; Fan, T.; Ren, Y.; Tang, X.; Xiao, F.; Liu, Y.; et al. Zinc-finger transcription factor zat6 positively regulates cadmium tolerance through the glutathione-dependent pathway in arabidopsis. Plant Physiol. 2016, 171, 707-719. [CrossRef] [PubMed]

78. Astolfi, S.; Zuchi, S.; Passera, C. Effect of cadmium on $\mathrm{H}^{+}$atpase activity of plasma membrane vesicles isolated from roots of different s-supplied maize (Zea mays L.) plants. Plant Sci. 2005, 169, 361-368. [CrossRef]

79. Ahmad, P.; Prasad, M. Environmental Adaptations and Stress Tolerance of Plants in the Era of Climate Change; Springer: New York, NY, USA, 2012; pp. 29-56. 
80. Pilon-Smits, E.A.; Hwang, S.; Lytle, C.M.; Zhu, Y.; Tai, J.C.; Bravo, R.C.; Chen, Y.; Leustek, T.; Terry, N. Over expression of atp sulfurylase in indian mustard leads to increased selenate uptake, reduction, and tolerance. Plant Physiol. 1999, 119, 123-132. [CrossRef] [PubMed]

81. Eltayeb, A.E.; Kawano, N.; Badawi, G.H.; Kaminaka, H.; Sanekata, T.; Shibahara, T.; Inanaga, S.; Tanaka, K. Overexpression of monodehydroascorbate reductase in transgenic tobacco confers enhanced tolerance to ozone, salt and polyethylene glycol stresses. Planta 2007, 225, 1255-1264. [CrossRef] [PubMed]

82. Yin, L.; Wang, S.; Eltayeb, A.E.; Uddin, M.I.; Yamamoto, Y.; Tsuji, W.; Takeuchi, Y.; Tanaka, K. Overexpression of dehydroascorbate reductase, but not monodehydroascorbate reductase, confers tolerance to aluminum stress in transgenic tobacco. Planta 2010, 231, 609-621. [CrossRef] [PubMed]

83. Shin, S.Y.; Kim, M.H.; Kim, Y.H.; Park, H.M.; Yoon, H.S. Co-expression of monodehydroascorbate reductase and dehydroascorbate reductase from Brassica rapa effectively confers tolerance to freezing-induced oxidative stress. Mol. Cells 2013, 36, 304-315. [CrossRef] [PubMed]

84. Johnston, E.J.; Rylott, E.L.; Beynon, E.; Lorenz, A.; Chechik, V.; Bruce, N.C. Monodehydroascorbate reductase mediates tht toxicity in plants. Science 2015, 349, 1072-1075. [CrossRef] [PubMed]

85. Hodges, D.M.; DeLong, J.M.; Forney, C.F.; Prange, R.K. Improving the thiobarbituric acid-reactive-substances assay for estimating lipid peroxidation in plant tissues containing anthocyanin and other interfering compounds. Planta 1999, 207, 604-611. [CrossRef]

86. Alexieva, V.; Sergiev, I.; Mapelli, S.; Karanov, E. The effect of drought and ultraviolet radiation on growth and stress markers in pea and wheat. Plant Cell Environ. 2001, 24, 1337-1344. [CrossRef]

87. Masato, O. An improved method for determination of 1-ascorbic acid and 1-dehydroascorbic acid in blood plasma. Clin. Chim. Acta 1980, 103, 259-268. [CrossRef]

88. Anderson, M.E. Determination of glutathione and glutathione disulfide in biological samples. Methods Enzymol. 1985, 113, 548-555. [PubMed]

89. Ellman, G.L. Tissue sulfhydryl groups. Arch. Biochem. Biophys. 1959, 82, 70-77. [CrossRef]

90. Duan, G.-L.; Hu, Y.; Liu, W.-J.; Kneer, R.; Zhao, F.-J.; Zhu, Y.-G. Evidence for a role of phytochelatins in regulating arsenic accumulation in rice grain. Environ. Exp. Bot. 2011, 71, 416-421. [CrossRef]

91. Nakano, Y.; Asada, K. Hydrogen peroxide is scavenged by ascorbate-specific peroxidase in spinach chloroplasts. Plant Cell Physiol. 1981, 22, 867-880.

92. Smith, I.K.; Vierheller, T.L.; Thorne, C.A. Assay of glutathione reductase in crude tissue homogenates using 5, 5'-dithiobis (2-nitrobenzoic acid). Anal. Biochem. 1988, 175, 408-413. [CrossRef]

93. Li, Z.-S.; Zhen, R.-G.; Rea, P.A. 1-Chloro-2,4-dinitrobenzene-elicited increase in vacuolar glutathione-S-conjugate transport activity. Plant Physiol. 1995, 109, 177-185. [CrossRef] [PubMed]

94. Lappartient, A.G.; Touraine, B. Demand-driven control of root atp sulfurylase activity and so42-uptake in intact canola (the role of phloem-translocated glutathione). Plant Physiol. 1996, 111, 147-157. [CrossRef] [PubMed]

95. Riemenschneider, A.; Riedel, K.; Hoefgen, R.; Papenbrock, J.; Hesse, H. Impact of reduced O-acetylserine (thiol) lyase isoform contents on potato plant metabolism. Plant Physiol. 2005, 137, 892-900. [CrossRef] [PubMed]

96. Pinto, M.C.D.; Tommasi, F.; Gara, L.D. Enzymes of the ascorbate biosynthesis and ascorbate-glutathione cycle in cultured cells of tobacco bright yellow 2. Plant Physiol. Biochem. 2000, 38, 541-550. [CrossRef]

(C) 2017 by the authors. Licensee MDPI, Basel, Switzerland. This article is an open access article distributed under the terms and conditions of the Creative Commons Attribution (CC BY) license (http://creativecommons.org/licenses/by/4.0/). 